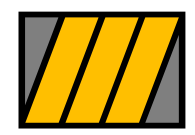

EsCuela de Negocios Universidad Torcuato Di Tella centro de investigación en finanzas

Documento de Trabajo 06/2011

\title{
Emerging economies in the 2000s: Real decoupling and financial recoupling
}

\author{
Eduardo Levy Yeyati \\ Universidad Torcuato Di Tella \\ and
}

Tomas Williams

Barcelona GSE

Almirante Sáenz Valiente 1010 C1428BIJ Buenos Aires • Tel: (54 11) 5169.7300

Fax: (54 11) 5169.7347 - Web site: http://www.utdt.edu 


\title{
Emerging economies in the 2000s: Real decoupling and financial recoupling
}

\author{
Eduardo Levy Yeyati $^{1}$ \\ Universidad Torcuato Di Tella
}

Tomas Williams

Barcelona GSE

\begin{abstract}
The paper documents an intriguing development in the emerging world in the 2000s: a decoupling from the business cycle of advanced countries, combined with the strengthening of the co-movements in the main emerging market assets that predates the synchronized selloff during the crisis. In addition, the paper tests the hypothesis that financial globalization, to the extent that it creates a common, global investor base for EM, could lead to a tighter asset correlation despite the weaker economic ties. While an examination of the impact of alternative financial globalization proxies yield no conclusive result, a closer look at global emerging market equity and bond funds show that the latter indeed foster financial recoupling during downturns, reflecting the fact that they trade near their respective benchmarks and respond to withdrawals by liquidating holdings across the board.
\end{abstract}

\footnotetext{
${ }^{1}$ We would like to thank Mariana Barrera for outstanding research assistance, and seminar participants at the World Bank, Brookings Institution, the Geneva Graduate Institute and Universidad de San Andres for their useful comments. Tatiana Didier kindly provided the data used in some of the tests in the paper. We would also like to thank The World Bank's CEO for financial support for this research agenda, as part of the 2011 flagship report on Latin American financial markets. The usual disclaimers apply.
} 


\section{Introduction}

Emerging markets (EM) advocates often emphasize their newly gained resilience to external shocks. Resilience, however, can be interpreted in several ways. In particular, it is expected to manifest differently according to whether it refers to economic performance, market interdependence, or the link between markets and economic activity. In this paper, we revisit the debate surrounding the different varieties of EM decoupling to document the recent behavior (both in the pre crisis bonanza and turbulent crisis period) on these three fronts, discuss the economic factors underlying the specific patterns in each case, and draw market and policy implications from these findings.

In particular, weexamine decoupling: (i) in the traditional sense, namely, business cycle synchronicity and sensitivity to the world economy (real decoupling); and (ii) as cross-market financial interdependence (financial decoupling), in the sense of the "betas" of EM credit, equity and currency returns to returns on the global market portfolio, as well as within-EM betas (a typical feature of the 90s); Finally, we center the debate around EM financial integration to the world (as the deepening of financial capital inflows) and its impact on financial ties of EM assets to those in the developed world.

The discussion is centered on EM assets. More specifically, we look at a sample of countries that represents what is usually labeled as emerging markets in the financial industry, following the Morgan Stanly Capital Index benchmark (MSCI) for individual countries and groups of countries, and focus our analysis on equity and, to a lesser extent, currency and hard currency sovereign bonds. As a comparison group, we include in the study a sample of advanced markets detailed in the Appendix.

We find that: (i) on the real front, rather than actually decoupling from the world, EM have diversified away from the US and the euro zone into emerging Asia (through international trade and the growing economic importance of China); (ii) on the market front, despite the real decoupling, the co-movement between EM and global assets (as measured by the EM betas to developed markets return) have risen in the late 2000s, even before the 2008-2009 crisis.

Why hasreal decoupling not provided more "room" for assets from fundamentally sound EM to decouple as well? A priori, financial globalization (FG), to the extent that it internationalized 
EM's investor base, could be the explanation for the tighter co-movement (as suggested, e.g., by Didier et al., 2010 for a broader country sample). While, a closer look at the impact of traditional FG proxies yield a negative result, capital flows from global and global emerging equity and bond funds indeed foster financial recoupling during downturns, reflecting the fact that they trade near their respective benchmarks and respond to withdrawals by liquidating holdings across the board.

The paper is organized as follows. Section 2 compares alternative definitions of EM. Section 3 examines real decoupling. Section 4 looks at credit, equity and currency betas over time to document the financial recouping in recent years. Section 5 explores the link between EM betas and alternative measures of FG. Finally, section 6 summarizes the results and concludes.

\section{A map of the emerging world}

While the buzzword "emerging", alternatively attached to markets and economies has been around for 30 years, the connotation of the term has changed dramatically over time. ${ }^{2}$ From an empirical perspective, emerging markets came into their own as an asset class only in the early 1990s, as the post-Bretton Woods financial globalization trend that consolidated in advanced countries in the $1980 \mathrm{~s}$ moved on to the developing world. ${ }^{3}$ Therefore, evaluating their performance starting in the early 1980s (when many EM did not even exist as national entities) could be greatly misleading.

The fact that "emerging" often denotes financial and economic aspects interchangeably opens the door for some divergence in the way the EM group is populated. There are several criteria according to which emerging economies can be identified and classified including: geography (acknowledging the incidence of regional ties) as in the many regional EM equity indexes; economic development (typically proxied by national income); and market infrastructure (often associated with one specific market), as in the FTSE classification, or economic size and

\footnotetext{
${ }^{2}$ As the story goes, the IFC staffer Antoine van Agtmael coined the term in 1981 to elude the negative connotation of the then popular "third world" label, at a time at which there was practically no foreign portfolio investment in those markets.

${ }^{3}$ Obstfled and Taylor (2002) provide a useful historical perspective.
} 
geopolitical influence, as in the BRIC category ${ }^{4}$ Moreover, the conventional (but often disputed) growth convergence view would suggest a negative correlation between growth upside and income (often used to screen advanced from emerging economies). A casual examination of the link between per capita GDP and IMF growth forecasts points in the same direction(Figure 1).

At any rate, a quick glance at different EM groupings reveals mostly coincidences in the broad breakdown, but some important differences within the EM tier (Table 1). Hong Kong,Israel, Singapore, and sometimes South Korea are regarded as advanced based on income and stock market development, although they are still treated as emerging for fixed income industry analysts. On the other corner, Chile's low income and less-than-stellar equity markets understate its economic progress and its developed bond market.

We do not intend to settle this semantic question in this series. Rather, as shown in Table 1, weuse here a standard broad EM grouping that could change due to data availability in some sections. In addition, for some exercises we look at a group of advanced markets as benchmark.

\section{Real decoupling and growth convergence}

One of the arguments often used by emerging markets (EM) advocates highlights that, because of the natural diversification in the sources of economic growth (due to increased openness and globalization) or because of structural changes and policy improvements, emerging economies have become more resilient to changes in the global context (see. E.g., The Economist, 2009). If, in the 1990s, whenever the world caught a cold EM got pneumonia, past financial crises would have immunized emerging economies so that, if anything, when in 2008 the G7 got pneumonia, EM just got a cold.

However, this popular decoupling argument is both less straightforward and more controversial than what its narrative suggests. For starters, common measures of decoupling tell a different story. On the empirical side, the share of the growth variability explained by the first principal component of quarterly growth for a group of developed and EM economies has increased sharply

\footnotetext{
${ }^{4}$ Along the same lines, newly industrialized countries (NICs) is a category between developed and developing countries, which includes Brazil, the People's Republic of China, India, Malaysia, Mexico, Philippines, South Africa, Thailand and Turkey.
} 
in the 2000s (Figure 2), and the same (albeit smaller) increases can be found by looking at crosscountry correlations (Rose, 2009).

Interestingly, the correlation of business cycles, the measure of decoupling that became standard in the economic literature, mixes sensitivity and amplitude. For example, the correlation between EM and G7 output, $\rho_{E M, G 7}=\beta_{E M, G 7}\left(\frac{\sigma_{E M}}{\sigma_{G 7}}\right)$ can increase with the beta between the two as well as with the ratio of output volatilities. Thus, the Great Moderation of the pre-crisis period (to the extent that it reduced $\sigma_{G 7}$ ) and a home-grown EM crisis (to the extent that it rises $\sigma_{E M}$ ) could increase the correlation even if the beta between the two countries remains unaltered. ${ }^{5}$ On the other hand, pure synchronicity measures (see, e.g., Mink and de Haan, 2007), while closer to the canonical definition of decoupling, are silent about the economic relevance of the connection.

At any rate, results using these measures are rather disappointing, as evidence of decoupling is seldom found: if anything, the 2000s seems to have witnessed an increase in the correlations of EM and G7 cycles (Figure 3). ${ }^{6}$ By contrast, with a few exceptions, EM have been exhibiting growth outperformance that, according to most forecasts, will continue in the next few years (Figure 4).

Sensitivity to global shocks is a key aspect of decoupling from the perspective of the risk associated to EM assets, where we careas much about how much EM volatility would result from a given global shock as the timing of the response.It is also critical in the context of the new EM debate (namely, the degree of progress the main emerging economies have made since the financially challenging 1990s). After all, if a global crisis, by definition, hits everybody, EM resilience and quality cannot be judged by the fact that they responded to last year's global shock, but rather by how much and for how long. The natural way to test whether EM sensitivity to global growth has declined over the years is to regress EM growth on G7 growth and evaluate how the coefficients (EM growth "betas" to the developed world) have evolved since the inception of EM as an asset class in 1993. Splitting the sample in an early (1993-99) and a late

\footnotetext{
${ }^{5}$ The same caveat applies to a comparison of the explanatory power of time-varying global factors based on the $\mathrm{R}^{2}$ (as in Kose et al., 2008) since $\mathrm{R}_{\mathrm{EM}, \mathrm{G} 7}^{2}=\rho_{\mathrm{EM}, \mathrm{G} 7}^{2}$.

${ }^{6}$ HP filtered output growth yields remarkably similar results. Rose (2009) reports and discusses different versions of this exercise. Walti (2009) applies Mink and de Haan's (2007) synchronicity measure based on the product of output gaps: $\left(\operatorname{gap}_{\mathrm{i}} /\left|\operatorname{gap}_{\mathrm{i}}\right|\right) *\left(\operatorname{gap}_{\mathrm{j}} /\left|\operatorname{gap}_{\mathrm{j}}\right|\right)$ which is equal to $\operatorname{sign}\left(\operatorname{gap}_{\mathrm{i}} * \operatorname{gap}_{\mathrm{j}}\right) * 1$, for the two-country or two-region case.
} 
(2000-Q3 2010) period, and assuming for simplicity that trend growth remained stable within each sub-period, the specification is simple enough:

$$
\begin{aligned}
& \Delta \ln \left(G D P_{i t}\right)=\alpha+\beta_{1} \Delta \ln \left(G D P_{G 7, t}\right)+\beta_{2} \Delta \ln \left(G D P_{G 7, t}\right) * D_{\text {late }}+\beta_{3} \Delta \ln \left(G D P_{\text {China }, t}\right)+ \\
& \beta_{4} \Delta \ln \left(G D P_{\text {China }, t}\right) * D_{\text {late }}
\end{aligned}
$$

a regression of the annual q/q growth rate of country $i$ 's cyclical output (relative to a log linear GDP trend) on the G7 and Chinese cycles, based on quarterly data, identifying the late period (2001-Q3 2010) with an interacting dummy. In passing, such a specification also allows us to estimate the long-term growth convergence (the EM "alphas") as the constant of the regression.

Note that we deliberately exclude China from the EM sample. For sheer size and growth dynamics, China represents a class in itself that, if grouped with other EM, could bias the conclusions of this exercise (as it does, most notably, in the typical analysis of EM aggregate output). Indeed, it remains a global driver that should be treated as an additional exogenous force behind EM growth and, thus,beincluded as an additional control, as we do here.

Table2 summarizes the results. The first thing to note is the fact that emerging economies display mostly "positive alphas" relative to the G7 group: a median $2.5 \%$ growth differential (Column 4) per year over the whole period, roughly in line with the back-of-the-envelope illustration in Figure 5. Is the elusive growth convergence finally materializing in the emerging world? While it is still far too early to judge, at first glance their relative growth performance is not inconsistent with the convergence view, not only vis a vis developed economies but, most strikingly, within the emerging group as well (Figure 4).

Regarding decoupling per se, in the traditional specification in which global growth is represented by the G7, the EM betas appear stable and high. In other words, there seems to have been no decoupling in the past decade, a finding mostly in line with the results in the recent economic literature (Rose, 2009; Wälti, 2009).

However, the data paint a different picture once we include China as a separate control: the explanatory power of the G7 clearly diminishes in the latest period, at the expense of the Chinese 
influence (columns 2 and 5). ${ }^{7}$ Reassuringly, the explanatory power of the new specification is significantly larger in all cases -particularly, as expected, in Asian economies and commodity exporters. ${ }^{8}$ In other words, the "coupling", understood as sensitivity to global growth, continues to be there -but it seems to have moved to the Far East.Predictably, an important share of the renewed resilience of EM due to the China factor is explained by the positive effect of the surge in commodity prices (column 7), in turn associated with Chinese growth (column4).The same conclusions can be drawn from the country-by-country regressions (median figures of which are reported in columns 4 to 6 in the table).

The finding that China has increased (and therefore helped diversify) the global influence on open economies is less trivial once we compare with our sample of non-G7 advanced economies, which show the negative of EM: a weak China effect and a global influence that appears to have remained high over time (Table 3).

As a robustness exercise, we replicate the same estimations but for a higher frequency proxy of growth, industrial production indexes. We computed annual growth rates $(\mathrm{m} / \mathrm{m})$ in emerging and advanced economies and run panel estimations of (1). Results are presented in Table 4. As before, EM have outperformed G7 growth also in terms of industrial production (column 1), and while the explanatory power of G7 decreased in the late period (2001-2010M09), the importance of China has grown consistently for emerging countries. On the other hand, non-G7 advanced markets have maintained close ties with G7 industrial production, while their relationship with China is negative under this growth proxy.

This phenomenon of decoupling with G7 and coupling with China is further illustrated in Figure 6, where we compute G7 and China betas from the following panel estimation:

$$
\Delta \ln \left(G D P_{-} i t\right)=\alpha+\beta_{G 7} \Delta \ln \left(G D P_{G 7, t}\right)+\beta_{C h i n a} \Delta \ln \left(G D P_{C h i n a}\right)
$$

This figure shows steadily (with some jumps due to the global financial crisis)decreasing G7 betas and marked growing China betas for out two growth proxies.

\footnotetext{
${ }^{7}$ This pattern does not depend on the assumption of a constant linear trend: de-trending output using the standard Hodrick-Prescott filter and estimating betas and alphas on the growth rate of the cycle yield roughly the same conclusion.

${ }^{8}$ Country-by-country results are available on request. 
Our results in this section are based upon the assumption that China is an independent engine of growth for EM, and its relationship with G7 growth is minor. As a way toillustrate the fact that China has been going its own way is to compute the principal components of growth for a G8 group comprised of the G7 + China. As the weights of the first two PC indicate (Figure 7), Chinese growth is captured by the second component, orthogonal to the first component that explains other G7, with Japan sitting halfway between other advanced economies and China.

This is further confirmed by country regressions of growth against the first two principal components (Figure 8):G7 countries are largely explained by the first one, China by the second one. In other words, we can safely say that, in the period under study, China represented an independent (and, based on Table 2, quite influential) new engine of emerging market growth.

\section{Financial recoupling}

A common misperception among EM advocates and practitioners is the idea that the newly gained policy autonomy and macroeconomic resilience to external shocks have enhanced the importance of a country's fundamentals as drivers of asset performance - a view typically contradicted by the data, which reveal a steady influence of global factors and persistently high betas. ${ }^{9}$

As before, we proceed in two steps. First, we examine whether the degree of assets price comovement estimating the share of time variability explained by the first principal component (PC1), this computed based on EM asset performance, and regress country-specific equity and FX returns, and CDS spread changes, on the PC1 constructed for each EM asset class, to get the average R2. As can be seen in Figure 9, the portion explain by PC1 is considerable in both cases, and has been growing over time (even before the 2008-2009 selloff).

In turn, $\mathrm{PC} 1$ is highly correlated with global factors, indicating that most of the co-movement displayed by EM assets comes from global influences or globally synchronized shocks (Table 5).

\footnotetext{
${ }^{9}$ Much as in the case of real decoupling discussed above, the drawbacks of using standard correlations to estimate market interdependence have been repeatedly highlighted in the finance literature, most notably Forbes and Rigobon (2002).
} 
Have the betas of EM assets to global assets come down in recent years? This is readily illustrated by a back-of-the-envelope estimation of betas relative to standard global proxies for each of the relevant markets. Specifically, we run country-by-country regressions of monthly log changes in MSCI country equity indexes, exchange rates and credit spreadson log changes in the S\&P 500, Broad Dollar Index, and US, respectively, to estimate alphas and betas as the ordinate and the coefficient from the regressions. ${ }^{10} \mathrm{We}$ focus on two time periods: early (2000-2004) and late (2005-2010), and we split the latter into a tranquil period (2005-2008M02) and a longer late period including the crisis (2005-2010). We replicate the exercise for quarterly and annual changes to examine whether longer time horizons enhance the effect of fundamentals at the expense of global markets.

As Figure 10clearly shows, betas have remained persistently high in the second half of the 2000s, even as we lower the sampling frequency to allow for short-term co-movement to dissipate (Table 6 report the group means and medians).Equities betas have remained close to 1 , while credit betas (sovereign bond spreads vis a vis high yield corporate spreads in advance countries) and exchange rate betas have generally increased. Table 6 also shows that high betas are not a result of the global financial crisis, as the pre-crisis period (2005-2008M02) presents betas in EM's assets that are greater or equal to betas during the early 2000s. Interestingly, this change in global betas is not idiosyncratic to EM, as it also applies to the advanced economies in our sample. However, financial recoupling in these economies have less strength than in EM, and is particularly found in equity markets and to a less extent in FX markets. ${ }^{11}$

To further investigate financial recoupling we performed panel estimations instead of country-by-country regressions of log changes in EM assets against global assets. Results are summarized in Table 7. For the three assets under consideration, we observe financial recoupling during the late 2000s even when we remove the crisis period (2008M03-2009M03). ${ }^{12}$ Our results are also in line with Dooley and Hutchinson (2009). In their study, they conclude that emerging markets experienced greater financial transmission during the worst period of the

\footnotetext{
${ }^{10}$ We use the S\&P, Broad Dollar Index and US HY instead of broader global indexes to be able to estimate alphas and betas for the advanced markets we used for comparison in the previous piece of this series. Estimating equity betas to the global MSCI yields comparable results. We choose MSCI equity indexes to local stock market indexes to concentrate on the more liquid, globally traded stocks used in cross-border operations.

${ }^{11}$ Sovereign debt in advanced economies is largely domestic and denominated in local currency, hence not directly comparable with EM credit.

${ }^{12}$ Financial recoupling is also present with semi-annual and annual log changes. These results are not presented for brevity but are available upon request.
} 
global financial crisis (i.e. betas increased even more during this financial turmoil). However, Dooley and Hutchinson (2009) analyze the financial recoupling-decoupling hypothesis comparing the period going from early 2007 to summer 2008 with the Lehman and post-Lehman period of the crisis. ${ }^{13}$ In here, we go a little further, by findng that during the 2000s EM have not decouple, financially speaking, from global assets. Furthermore, our evidence points towards a financial recoupling during this period, that was taking place even before the global financial crisis of 2008/2009.

\section{Is Financial recoupling the result of financial globalization?}

Why have market betas to global drivers remained so high despite the more diversified economic pattern displayed by EM in the 2000s? In principle, stable to higher betas could be seen as the natural consequence of financial globalization, to the extent that the latter tends to increase the global nature of EM's investor base, thereby making it more homogeneous.As the global investors increasingly participate in emerging markets (Figure 11), the importance of global factors coming from the developed world increases at the expense of within-EM factors that represented the typical source of contagion in the 1990s.

On the other hand, in the late 2000s, emerging assets prices have exhibited a clear high-beta, high-alpha pattern relative to global assets (Figure 12);namely, a tightly correlated oscillation around clearly diverging trends (in line with results in Table 7). ${ }^{14}$

In this section, we explore whether this patter (particularly, the high beta) is related to (or is a consequence of) financial globalization, To do that, we focus on the three EM assets classes previously discussed: credit, currencies and equity.

\footnotetext{
${ }^{13}$ As we do, they analyze equity, debt and FX markets in EM. They use daily data and analyze whether news emanating from the US had more or less impact comparing these two phases of the US subprime crisis.

${ }^{14}$ By alphas and betas we refer to the coefficients of a simple regression of return of the EM asset on the return of a comparable market portfolio (both in excess of the risk free rate), which in turn are associated, respectively, with (diversifiable) idiosyncratic and (non diversifiable) systemic returns.
} 


\section{a. Financial globalization: What do we talk about? ${ }^{15}$}

Despite being the subject of a rich and growing literature, the concept of financial globalization has been defined in various, often-uncorrelated ways in the academic work. As a result, assessing a country's integration with international financial markets remains a complicated and controversial task.

Today it is well accepted that the extent to which globalization affects asset prices and, more generally, is related to the actual intensity and sensitivity of cross-border flows, regardless of existing controls and restrictions usually at the core of de jure globalization measures. ${ }^{16}$ For example, many tightly regulated economies are the recipients and sources of important capital flows (and are therefore financially globalized), whereas other control-free economies are shunned by international investors and, as a result, are isolated from global market swings and trends. In turn, the empirical literature typically measured de facto globalization as the ratio of foreign asset positions (relative price-adjusted cumulative balance of payments flows) to GDP, as in Lane and Milessi-Ferreti (2006 and 2007; henceforth, LMF). ${ }^{17}$

It should be noted, however, that the stock size of cross border holdings, while probably a good indicator of geographical diversification and international risk sharing, may not be the best summary statistic of de facto FG in the traditional sense of capital mobility and international arbitrage, since important gross flows in and out of a country over a given year are perfectly consistent with a relatively small net -as well as with small cumulative flows over longer periods. As a result, to the extent that foreign asset holdings largely reflect cumulative flows, intense flows could be consistent with a limited geographical diversification of assets and liabilities. Conversely, the existence of large foreign asset holdings (for example, as a result of capital flight) does not necessarily imply frequent rebalancing and cross-market arbitrage. Thus,

\footnotetext{
${ }^{15}$ This section borrows from Levy Yeyati and Williams (2010).

${ }^{16}$ The literature generally distinguishes between de jure and de facto financial globalization (Kose, Prassad, Rogoff, Wei, 2009): where the former is based on regulations, restrictions and controls over capital flows and asset ownership, the latter is related to the intensity of capital flows and cross-market correlation and arbitrage.

${ }^{17}$ Kraay, Loayza and Ventura (2005) report a similar dataset on country's asset positions. An alternative approach to FG relies on price convergence, an application of the Law of one Price to financial markets. Measures within this group point at transaction costs and regulation that inhibit market arbitrage, and usually compare prices of identical or similar assets trading in different markets. On this, see Levy Yeyati, Schmukler and Van Horen (2008) and references therein.LMF and the Chinn-Ito index are the de facto and de jure measures of choice in recent work on determinants and implications of FG (see, i.a., Kose, Prasad, Taylor, 2009 and Rodrik, and A. Subramanian, 2009).
} 
depending on the specific issue at hand, stock holdings, capital flows or both may prove informative.

In addition, the investor behind a particular flow may also be relevant to understand FG. For example, a passive buy and hold portfolio investor may behave closer to real investors (FDI), with limited turnover (flows) for a given holding. By contrast, institutional or professional investors would tend to be more sensitive to expected return differentials, with both a larger turnover and a bigger impact in terms of price action its correlation across markets and with respect to economic fundamentals. Global mutual funds are a case in point in this regard. While, as a subset of cross-border holdings, they are generally a poorer proxy than other more comprehensive measures, they may shed some additional light on the role of the international investor as a financial transmission channel. To the extent that these funds tend to keep close to their benchmarks, they may introduce an additional source of market co-movement, particularly in the event of sharp swings in global risk aversion (when contributions and redemptions lead to purchases and sales in all markets at the same time).

In this light, we try to analyse different measures of de facto FG by their advantages and disadvantages of using them as proxies of financial globalization in emerging markets. More precisely, we look at two different sources: (i) US Treasury's TIC monthly survey data on the market value of sales and purchases, and stocks holdings of foreign securities by US-domiciled investors (by the market where the security is issued); and (ii) EPFR's monthly data on global fund flows and assets under management (AUM), (by issuing country).

In our study, we are interested in asset prices on a monthly basis, and to address whether financial recoupling (or greater financial contagion) in the late 2000s was associated with financial globalization. At first sight, frequency and length problems arise with both Lane and Milesi-Ferretti's (2007) and BoP statistics. Annual foreign stocks from LMF are available until 2007, and are inadequate to analyse asset prices and financial globalization in the late 2000s, particularly at times when the global financial crisis may have significantly modified gross foreign asset positions. On the other hand, while updated BoP statistics are available, they are usually reported on a quarterly or an annual basis. To study whether greaterflow intensity generates the monthly asset correlation behind financial recoupling, we need higher frequency data such as the U.S. Treasury's TIC and EPFR data. 
TIC data collect cross-border holdings of securities measured at market value through security-level surveys (that is, information is reported separately for each security) that conflate data from custodians, issuers, and investors. As the data is collected by the US Treasury, it comprises transactions between U.S. residents and counterparties located outside the United States involving six types of securities, includingfour domestic (U.S. Treasury bonds and notes, bonds of U.S. government corporations and federally-sponsored agencies, U.S. corporate and other bonds, and U.S. corporate and other stocks) and two foreign (foreign bonds and foreign stocks). We compute liability flows coming from the US as the difference between gross purchases and gross sales of foreign securities by US residents. In turn, EPFR data report the fund net flow to individual emerging economies, as well as the assets under management (AUM) by country.

There are differences between TIC and EPFR data. On the one hand, unlike annual TIC data, EPFR data is available at monthly (and, for a subset of funds, weekly) frequency. More importantly, the simple within-country correlation between both flow measures is rather low (Table 8), reflecting the distinct behavioral pattern between both sources: as we stated above, global funds tend to keep close to their benchmark, inducing correlation (as a result of global swings in risk appetite and exposure) and possibly exacerbating financial contagion, while the average TIC respondent would tend to trace less and to exhibit a more selective sensitivity to relative price changes.

A degree of complexity in the measurement of de facto FG is introduced by the normalization. On the one hand, normalization by the (US dollar) GDP looks natural for issues related with the country's wealth diversification away from domestic shocks (and exposure to external shocks). On the other hand, normalization by local market capitalization seems to be more appropriate when assessing cross-border flows as a source of price volatility and international contagion. The differences are not trivial: as we show in a companion paper (Levy Yeyati and Williams (2010)), whereas in the 2000s globalization in EM remained stable in terms of foreign market participation, it grew in terms of GDP reflecting the valuation effect of the equity rally before and after the 2008 slump. To avoid capturing these spurious price effects, here we normalize equity liability flows by local equity market capitalization and debt liability flows by the total outstanding debt of the recipient country. 
Yet another source of concern arises from the less-than-perfect correspondence between stocks holdings and the volume of flows. Levy Yeyati and Williams (2010) report that the relationship between the size (that is, the absolute value) of this year's flows and end-of-lastyear's holdings (based on holdings data from LMF and BoP flow data) is significant for EM equity and FDI but not for debt instruments. However, using EPFR's global fund data, they find that the link is significant and stronger for both equity and debt instruments. At any rate, to the extent that flows are only imperfectly characterized by initial holdings, it is useful to proxy globalization both by foreign liability stock (as is typically doen in the literature) and flow ratios.

\section{b. Globalization, benchmarking and financial recoupling}

Does foreign participation increase the market betas to global returns? Does FG amplify the response of cross-border flows and asset prices in times of global turmoil? A first look at the data appears to contradict this hypothesis. Although in principle there seems to be a significant link between holdings and betas (Didier et al, 2010) a closer look reveals that it is entirely accounted for by the group of non-EM developing frontier markets. ${ }^{18}$

Table 9 illustrates the point. The first column reproduces the main result in Didier et al. (2010), which tries to explain the financial channel behind the large post-Lehman betas, controlling for market moves with time dummies: US holdings from TIC data do not explain but significantly amplify the sensitivity of EM equity to global returns (measured from a regression of the monthly change in the local stock market index against monthly returns on the S\&P 500). However, as the next two columns reveal, the result is entirely driven by frontier markets: US equity holdings do not change significantly the impact of S\&P returns on equity returns in either developed or emerging economies. The same is true when, in the second half of the table, we drop the Lehman interaction and replace time dummies by S\&P returns (a specification closer to our focus on market betas, here assumed to be a linear function of US holdings). Given that flows and stocks are not always tightly correlated (and that, ultimately, it is the flow that influences the price action in these markets): does the test change when we use the volume (that is, the absolute value) of TIC equity liability flows? According to the results in column 9, the

\footnotetext{
${ }^{18}$ Tatiana Didier kindly provided the data for this table.
} 
answer is no -not surprisingly, since equity inflows tend to be closely correlated with foreign equity holdings (Levy Yeyati and Williams, 2011).

Figure 13 presents a graphical illustration of these results by plotting country-by-country equity betas against US holdings, and showing how, unlike in the case of frontier markets, the expected positive link between betas and FG fails to materialize.

As noted, there are important difference between the average international investor and the professional asset manager, not least of them the fact that the latter are usually benchmarked, which limits their decisions to small deviations from the market weights, forcing them to purchase or liquidate in all markets proportionally in the event of massive allocations or withdrawals from the asset class. In other word, global flows may explain the growing correlation of EM assets with US markets better than the holdings of the average U.S. resident investor.

With that in mind, in Table 10 we replicate the exercise in column 9 of Table 9using EPFR flow data. Now, we find a significant amplifying effect: larger fund flows (both in and out of individual countries) are associated with higher equity betas. Interestingly, the effect is asymmetric: as columns 2 and 3 show, the volume of fund flows plays a significant role only during equity sell-offs. A similar asymmetric pattern is found for credit spreads (relative to U.S. high yield corporate spreads) and currency returns (relative to the inverse of the Broad Dollar Index). ${ }^{19}$

The directional causation of the previous findings is not trivial. They could reflect the behavior of benchmarked professional investors facing contributions and redemptions while keeping a balanced portfolio. However, they could alternatively reflect money-chasing returns (or rushing to the exit) whereby asset managers increase their positions in countries with excess returns and cut their exposure in falling markets. To control for this possibility, we re-estimate our models in Table 11using Arellano-Bond panel estimator with external and internal instruments. As external instruments, we compute, for each country, capital flows to the rest of $\mathrm{EM}$, the assumption is that fund flows, which are highly correlated across EM, can only affect

\footnotetext{
${ }^{19} \mathrm{~A}$ digression should be made about currency markets. Because there is no data on currency flows to make comparable estimations, we use data from equity funds as a proxy. The assumption is that many professional investors go into equity markets usingunhedged positions, so that currency and equity cross-border flows are closely correlated.
} 
returns in the host country. As internal instruments we use the first lag of the dependent variables. Results are in line with our previous estimations (only for currencies we fail to recover a significant effect): indeed, the interaction terms for equity and credit gest bigger at the expense of the simple betas, suggesting that the amplifying effect could be even larger than reported in the previous tables.

Evidence of asset co-movement induced by the incidence of benchmarked international funds can also be seen in the investment decision of fund managers. Country weights tend to remain close to their benchmarks, and at any rate they adjust slowly even in times of turmoil. Alternatively, flows in and out of individual countries mimic those stable weights, which, in times of liquidation, induce correlated sales and price action.

The underpinnings of benchmarking can be illustrated based on EPFR's individual fund data on flows and country weights.For the sample of emerging market-dedicate funds, panel regressions of today's country weights against last period's country weights and country returns (with and without time effects, and with country-time effects) show that the time correlation of weights is close to one (Table 12). This correlation reappears almost as strongly when we compute weights using the funds aggregate (which includes EM and country-dedicated as well as global funds -the same sample used in the decoupling regressions of Table 10): monthly weight changes tend to be quite small. As can be seen in columns 2 and 6, the persistence of country weights is not altered in crisis periods.

In turn, it is easy to show how the influence of market weights on the cross-country correlation of fund flows increases in times of massive swings in fund allocations. After netting out monthly fund returns, we can decompose individual fund flows to a given country as:

$$
\frac{\text { Flow }_{i, j, t}}{A U M_{i, t-1}}=w_{i, j, t}-w_{i, j, t-1}+w_{i, j, t} * \frac{\text { Flow }_{i, t}}{A U M_{i, t-1}}
$$

which, following the results of Table 6 and expressing $w_{i, j, t}$ as a function of $w_{i, j, t-1}$, yields

$$
=f\left(w_{i, j, t-1}\right)+g\left(w_{i, j, t-1}\right) * \frac{\text { Flow }_{i, t}}{A U M_{i, t-1}}
$$

with $f^{\prime}<0, g^{\prime}>0$, where Flow $i, j, t, A U M_{i, j, t}$ and $w_{i, j, t}$ are flows, assets under management and weights in fund ito country $j$ at time $t$. The first term corresponds to re-allocationflows due to 
portfolio rebalancing, whereas the second represents new flows, allocated according to today's weights. It follows that, in times of little or no new flows to equity funds, the second term becomes irrelevant and the correlation between country flows and past weightsdue to rebalancing is negative. By contrast, in times of massive inflows or outflows, the second term dominates, and therefore hysteresis in portfolio composition (as noted, influenced by the composition of the benchmark) induces a strong cross-country correlation of flows in line with the results in Table 10.

\section{Final remarks}

The paper documented an intriguing result: on the one hand, business cycles in emerging markets have gradually decoupled from those in advanced economies, as trade diversification, commodity strength and, particularly, the emergence of China took over the G7 as the main global factor behind output fluctuations in the emerging world. On the other, cross-market comovements (market betas, even at lower frequencies) have remained high or even grown higher in the past few years, even before the synchronized sell off of 2008 took place.

Are these contrasting findings due to the globalization of emerging markets, namely, the increasing share in the hands of global investors prone to cross market arbitrage and proxy hedging? Our preliminary tests, using alternative stock and flow measures of FG, provide mixed answer to this question. While a closer look at the impact of traditional FG proxies yields negative results, capital flows from global equity and bond funds indeed foster financial recoupling during downturns, reflecting the fact that they trade near their respective benchmarks and respond to withdrawals by liquidating holdings across the board. Perhaps predictably, financial integration, in the sense of exposure to a common pool of global investors, strengthens the impact of swings in the risk appetite and liquidity preferences of those investors, much in the same way as the internationalization of banks makes local banking sectors more sensitive to liquidity shocks in global markets. That said, the relatively muted role played by country fundamentals in asset returns even at longer frequencies deserves a more careful and detailed look. 


\section{References}

Bekaert, Geert, and Harvey, Campbell, (1998), "Capital flows and the behavior of emerging market equity returns," NBER Working paper, 6669.

Chinn,Menzie, and Ito, Hiro, (2007), "Price-based Measurement of Financial Globalization: A Cross-Country Study of Interest Rate Parity” Pacific Economic Review vol. 12 (4), pp. 419-444.

Chinn,Menzie, and Ito, Hiro,(2008). “A New Measure of Financial Openness,"Journal of Comparative Policy Analysis, vol. 10(3), pp. 309-322.

Dennis, Quinn, and Inclán, Carla (1997), "The Origins of Financial Openness: A Study of Current and Capital Account Liberalization”, American Journal of Political Science, vol. 41, pp. 771-813.

Didier, Tatiana, Love, Inessa, and Martinez Peria, Soledad, (2011), "What Explains Comovement in Stock Market Returns during the 2007-2008 Crisis?," International Journal of Finance and Economics, forthcoming.

Dooley, Michael, and Hutchinson, Michael, (2009), “Transmission of the U.S. Subprime Crisis to Emerging Markets: Evidence on the Decoupling-Recoupling Hypothesis," Journal of International Money and Finance, vol. 28 (8), pp. 1331-1349.

Forbes, Kristin, and Rigobon, Roberto, (2002), "No Contagion, Only Interdependence: Measuring Stock Market Co-movements,"Journal of Finance, vol. 57, pp. 2223-2261.

Kaminsky, Graciela, and Schmukler, Sergio, (1998), "What Triggers Market Jitters? A Chronicle of the Asian Crises,"Journal of International Money and Finance, vol. 18 (4), pp. 537-60.

Kose, Ayhan,Otrok, Cristopher, and Prasad, Eswar, (2008), "Global business cycles: Convergence or decoupling?’NBER Working Paper 14292.

KoseAyhan, Prasad, Eswar, Rogoff, Kenneth, and, Shang-Jin, Wei, (2009), "Financial Globalization and Economic Policies,” C.E.P.R. Discussion Papers 7117.

Kose, Ayhan, Prasad, Eswar, and Taylor, Ashley, (2011), "Thresholds in the Process of International Financial Integration," Journal of International Money and Finance, vol. 30 (1), pp. 147-179. 
Kraay, Aart, Loayza, Norman,Servén, Luis, and Ventura, Jaume (2005), "Country Portfolios" Journal of the European Economic Association, MIT Press, vol. 3(4), pp. 914-945.

Levy Yeyati, Eduardo, Schmukler, Sergio, and Van Horen, Neeltje (2008), "Crises, capital controls, and financial integration," Policy Research Working Paper Series 4770, The World Bank.

Levy Yeyati, Eduardo, Martinez Peria,Maria Soledad, and Schmukler, Sergio, (2010), "Deposit Behavior under Macroeconomic Risk," Journal of Money, Credit, and Banking, vol. 42 (4), pp. 585-614.

Levy Yeyati, Eduardo, and Williams, Tomas, (2011), "Financial Globalization in Emerging Economies: Much ado about Nothing?," Policy Research Working Paper Series 5624, The World Bank.

Mink, Jacobs, and de Haan, Jakob, (2007), "Measuring synchronicity and comovement of business cycles with an application to the euro area," CESifo Working Paper 2112.

Obstfeld, Maurice, and Taylor, Alan, (2002), "Globalization and Capital Markets", NBER Chapters in Globalization in Historical Perspective, pp. 121-188.

Philip, Lane, and Milesi-Ferretti,Gian, (2006), "The External Wealth of Nations Mark II: Revised and Extended Estimates of Foreign Assets and Liabilities, 1970-2004,” IMF Working Paper, March.

Philip, Lane, and Milesi-Ferretti,Gian, (2007), "The External Wealth of Nations Mark II," Journal of International Economics, vol. 73, pp. 223-250.

Rodrik,Dani, and Subramanian, Arvind, (2009). "Why did financial globalization disappoint?," IMF Staff Papers, vol. 56(1), pp. 112-138.

Rose, Andrew, (2009), “Debunking 'decoupling”, Vox EU, August 1, 2009.

Wälti, Sébastian, (2009), “The myth of decoupling,” mimeo, Swiss National Bank.

The Economist (2009), Decoupling 2.0, 21 May. 
Table 1

A map of the emerging world

This table presents countries used as emerging markets (EM) in this paper, and their classification among lists performed by financial companies, their per capita GDP in USD in 2009 and their 5-year average GDP forecast (2011-2015). Source: IMF WEO April 2010, FTSE, MSCI, The Economist, S\&P, Dow Jones.

Country FTSE MSCI The Economist S\&P Dow Jones

\begin{tabular}{|c|c|c|c|c|c|c|c|c|}
\hline Argentina & - & - & - & - & EM & 9138.2 & 4.56 & EM \\
\hline Brazil & EM & EM & EM & EM & EM & 10816.5 & 4.20 & EM \\
\hline Chile & EM & EM & EM & EM & EM & 11828.0 & 4.80 & EM \\
\hline China & EM & EM & EM & EM & EM & 4382.1 & 9.52 & EM \\
\hline Colombia & EM & EM & EM & & EM & 6273.4 & 4.51 & EM \\
\hline Czech Republic & EM & EM & EM & EM & EM & 18288.3 & 2.71 & EM \\
\hline Egypt & EM & EM & EM & EM & EM & 2788.8 & 4.40 & EM \\
\hline Hong Kong & EM & - & EM & - & - & 31590.7 & 4.46 & EM \\
\hline Hungary & EM & EM & EM & EM & EM & 12879.3 & 2.93 & EM \\
\hline India & EM & EM & EM & EM & EM & 1264.8 & 8.10 & EM \\
\hline Indonesia & EM & EM & EM & EM & EM & 3015.4 & 6.68 & EM \\
\hline Israel & - & - & - & - & - & 28685.6 & 3.70 & EM \\
\hline Korea & - & EM & EM & - & - & 20591.0 & 4.18 & EM \\
\hline Malaysia & EM & EM & EM & EM & EM & 8423.2 & 5.18 & EM \\
\hline Mexico & EM & EM & EM & EM & EM & 9566.0 & 3.70 & EM \\
\hline Peru & EM & EM & EM & EM & EM & 5171.7 & 6.10 & EM \\
\hline Philippines & EM & EM & EM & EM & EM & 2007.4 & 4.98 & EM \\
\hline Poland & EM & EM & EM & EM & EM & 12300.1 & 3.75 & EM \\
\hline Russia & EM & EM & EM & EM & EM & 10437.5 & 4.38 & EM \\
\hline Singapore & - & - & EM & - & - & 43116.7 & 4.43 & EM \\
\hline South Africa & EM & EM & EM & EM & EM & 7157.8 & 4.09 & EM \\
\hline Taiwan & EM & EM & EM & EM & - & 18457.8 & 5.12 & EM \\
\hline Thailand & EM & EM & EM & EM & EM & 4991.5 & 4.56 & EM \\
\hline Turkey & EM & EM & EM & EM & EM & 10398.7 & 4.25 & EM \\
\hline
\end{tabular}

5-year avg. GDP

GDP per capita 2010

(USD, current prices) growth forecast \% This Paper 


\section{Table 2}

The Real Decoupling hypothesis among EM

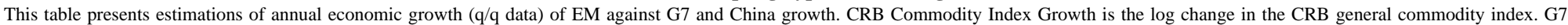

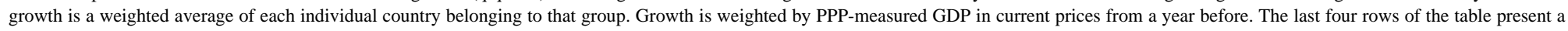

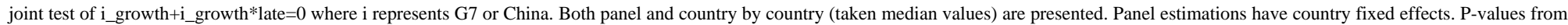
robust standard errors are presented in italics. *,** and *** denotes significance at the 10,5 and $1 \%$ level respectively. Source: IMF IFS Statistics, IMF WEO, Bloomberg.

\begin{tabular}{|c|c|c|c|c|c|c|c|}
\hline Country_Group & EM & EEM & EEM & EM & EM & EM & \\
\hline Estimations & Panel & Panel & Panel & $\begin{array}{l}\text { Country by Country } \\
\text { (median values) }\end{array}$ & $\begin{array}{l}\text { Country by Country } \\
\text { (median values) }\end{array}$ & $\begin{array}{l}\text { Country by Country } \\
\text { (median values) }\end{array}$ & OLS \\
\hline Variables & $\begin{array}{l}\text { Real GDP } \\
\text { Growth } \\
\end{array}$ & $\begin{array}{l}\text { Real GDP } \\
\text { Growth } \\
\end{array}$ & $\begin{array}{l}\text { Real GDP } \\
\text { Growth } \\
\end{array}$ & Real GDP Growth & Real GDP Growth & Real GDP Growth & $\begin{array}{l}\text { CRB Commodity } \\
\text { Index Growth } \\
\end{array}$ \\
\hline G7 Growth & $\begin{array}{c}0.509 * * * \\
0.000\end{array}$ & $\begin{array}{c}1.378 * * * \\
0.000\end{array}$ & $\begin{array}{c}1.168 * * * \\
0.000\end{array}$ & $\begin{array}{c}0.578 * * * \\
0.009\end{array}$ & $\begin{array}{c}1.436 * * * \\
0.007\end{array}$ & $\begin{array}{c}1.071 * * \\
0.029\end{array}$ & $\begin{array}{c}2.507 * * * \\
0.006\end{array}$ \\
\hline G7 Growth*Late & $\begin{array}{c}0.686 * * * \\
0.000\end{array}$ & $\begin{array}{c}-0.490 * * \\
0.000\end{array}$ & $\begin{array}{c}-0.508 * * \\
0.012\end{array}$ & $0.635 * *$ & $\begin{array}{c}-0.700 * \\
0.096\end{array}$ & $\begin{array}{c}-0.693 * \\
0.072\end{array}$ & \\
\hline China Growth & & $\begin{array}{c}0.809 * * * \\
0.000\end{array}$ & $\begin{array}{c}0.650 * * * \\
0.000\end{array}$ & & $\begin{array}{c}0.793 * * * \\
0.001\end{array}$ & $\begin{array}{c}0.498 * * \\
0.012\end{array}$ & $\begin{array}{c}2.817 * * * \\
0.001\end{array}$ \\
\hline China Growth*Late & & $\begin{array}{c}0.344 * * * \\
0.000\end{array}$ & $\begin{array}{c}0.252 * * * \\
0.000\end{array}$ & & $\begin{array}{c}0.333^{*} \\
0.096\end{array}$ & $\begin{array}{c}0.231 * \\
0.056\end{array}$ & \\
\hline CRB Commodity Index Growth & & & $\begin{array}{c}0.055^{* * * *} \\
0.000\end{array}$ & & & $\begin{array}{c}0.049 \\
0.128\end{array}$ & \\
\hline Constant & $\begin{array}{c}0.026 * * * \\
0.000\end{array}$ & $\begin{array}{c}-0.075^{* * * *} \\
0.000\end{array}$ & $\begin{array}{c}-0.053^{* * * *} \\
0.000\end{array}$ & $\begin{array}{c}0.025 * * * \\
0.000\end{array}$ & $\begin{array}{c}-0.053 * * \\
0.046\end{array}$ & $\begin{array}{l}-0.039 \\
0.152\end{array}$ & \\
\hline $\begin{array}{l}\text { Observations } \\
\text { R-squared }\end{array}$ & $\begin{array}{c}1389 \\
0.226\end{array}$ & $\begin{array}{r}1389 \\
0.322\end{array}$ & $\begin{array}{r}1389 \\
0.331\end{array}$ & $\begin{array}{c}71 \\
0.243\end{array}$ & $\begin{array}{c}70 \\
0.474\end{array}$ & $\begin{array}{c}70 \\
0.502\end{array}$ & $\begin{array}{c}70 \\
0.306\end{array}$ \\
\hline G7 Growth+G7 Growth*Late & $1.195 * * *$ & $0.888 * * *$ & $0.660 * * *$ & $1.032 * * *$ & $0.768 * * *$ & $0.418^{*}$ & \\
\hline China Growth+China Growth*Late & 0.000 & $\begin{array}{c}0.000 \\
1.153 * * * \\
0.000\end{array}$ & $\begin{array}{c}0.000 \\
0.902 * * * \\
0.000\end{array}$ & 0.000 & $\begin{array}{c}0.000 \\
0.877 * * * \\
0.007\end{array}$ & $\begin{array}{c}0.066 \\
0.754 * * \\
0.024\end{array}$ & \\
\hline
\end{tabular}




\section{Table 3}

Still coupling with G7 and not a relationship with China in advanced economies

This table presents estimations of annual economic growth (q/q data) of non-G7 AM against G7 and China growth. CRB Commodity Index Growth is the log change in the CRB general commodity index. G7 growth is a weighted average of each individual country belonging to that group. Growth is weighted by PPP-measured GDP in current prices from a year before. The last four rows of the table present a joint test of i_growth+i_growth*late $=0$ where i represents $\mathrm{G} 7$ or China. Both panel and country by country (taken median values) are presented. Panel estimations have country fixed effects. P-values from robust standard errors are presented in italics. *, ** and *** denotes significance at the 10,5 and $1 \%$ level respectively. Source: IMF IFS Statistics, IMF WEO, Bloomberg.

\begin{tabular}{|c|c|c|c|c|c|c|}
\hline Country Group. & AM & AM & AM & AM & AM & AM \\
\hline Estimations & Panel & Panel & Panel & $\begin{array}{l}\text { Country by Country } \\
\text { (median values) }\end{array}$ & $\begin{array}{l}\text { Country by Country } \\
\text { (median values) }\end{array}$ & $\begin{array}{l}\text { Country by Country } \\
\text { (median values) }\end{array}$ \\
\hline Variables & $\begin{array}{c}\text { Real GDP } \\
\text { Growth } \\
\end{array}$ & $\begin{array}{c}\text { Real GDP } \\
\text { Growth }\end{array}$ & $\begin{array}{c}\text { Real GDP } \\
\text { Growth } \\
\end{array}$ & Real GDP Growth & Real GDP Growth & Real GDP Growth \\
\hline G7 Growth & $\begin{array}{l}1.206^{* * *} * \\
0.000\end{array}$ & $\begin{array}{l}1.110 * * * \\
0.000\end{array}$ & $\begin{array}{l}1.284 * * * \\
0.000\end{array}$ & $\begin{array}{l}1.190 * * * \\
0.000\end{array}$ & $\begin{array}{l}1.284 * * * \\
0.000\end{array}$ & $\begin{array}{l}1.479 * * * \\
0.000\end{array}$ \\
\hline G7 Growth*Late & $\begin{array}{l}-0.176^{* * * *} \\
0.000\end{array}$ & $\begin{array}{c}-0.0348 \\
0.355\end{array}$ & $\begin{array}{c}-0.0340 \\
0.827\end{array}$ & $-0.122 *$ & $\begin{array}{c}-0.060 \\
0.242\end{array}$ & $\begin{array}{c}-0.062 \\
0.136\end{array}$ \\
\hline China Growth & & $\begin{array}{l}-0.145^{* * * *} \\
0.001\end{array}$ & $\begin{array}{c}-0.0231 \\
0.639\end{array}$ & & $\begin{array}{c}-0.069 \\
0.139\end{array}$ & 0.023 \\
\hline China Growth*Late & & $\begin{array}{c}-0.04 \\
0.355\end{array}$ & $\begin{array}{c}0.0351 \\
0.453\end{array}$ & & $\begin{array}{l}0.139 \\
-0.011 \\
0.242\end{array}$ & $\begin{array}{l}0.292 \\
0.035 \\
0.178\end{array}$ \\
\hline CRB Commodity Index Growth & & & $\begin{array}{l}-0.0429 * * * \\
0.000\end{array}$ & & & $\begin{array}{c}-0.028 \\
0.179\end{array}$ \\
\hline Constant & $0.003 * *$ & $0.020 * * *$ & 0.00247 & $0.001 *$ & 0.014 & $0.007^{*}$ \\
\hline Observations & $\begin{array}{r}0.012 \\
942\end{array}$ & $\begin{array}{r}0.000 \\
942\end{array}$ & $\begin{array}{r}0.701 \\
942\end{array}$ & $\begin{array}{c}0.093 \\
71\end{array}$ & $\begin{array}{c}0.249 \\
70\end{array}$ & $\begin{array}{c}0.092 \\
70\end{array}$ \\
\hline R-squared & 0.440 & 0.446 & 0.457 & 0.518 & 0.603 & 0.620 \\
\hline G7 Growth+G7 Growth*Late & $1.030 * * *$ & $1.075^{* * *}$ & $1.250 * * *$ & $1.068 * * *$ & $1.225 * * *$ & $1.417 * * *$ \\
\hline China Growth+China Growth*Late & 0.000 & $\begin{array}{c}0.000 \\
-0.185^{* * *} \\
0.004 \\
\end{array}$ & $\begin{array}{l}0.000 \\
0.012 \\
0.872 \\
\end{array}$ & 0.000 & $\begin{array}{c}0.000 \\
-0.083 \\
0.234 \\
\end{array}$ & $\begin{array}{c}0.000 \\
0.058 \\
0.161 \\
\end{array}$ \\
\hline
\end{tabular}


Table 4

Real decoupling for Industrial Production (AM and EM, panel estimations)

This table presents estimations of annual industrial production growth ( $\mathrm{m} / \mathrm{m}$ data) of EM and non-G7 AM against G7 and China growth. CRB Commodity Index Growth is the log change in the CRB general commodity index. G7 growth is a weighted average of each individual country belonging to that group. Growth is weighted by PPP-measured GDP in current prices from a year before. The last four rows of the table present a joint test of $i_{-}$growth $+\mathrm{i}$ growth*late $=0$ where $\mathrm{i}$ represents G7 or China. Panel estimations have country fixed effects. P-values from robust standard errors are presented in italics. *, ** and *** denotes significance at the 10,5 and $1 \%$ level respectively. Source: IMF IFS Statistics, IMF WEO, Bloomberg, GEM World Bank.

\begin{tabular}{|c|c|c|c|c|c|c|c|}
\hline Country Group & EM & EM & EM & $\mathrm{AM}$ & $\mathrm{AM}$ & $\mathrm{AM}$ & \\
\hline Estimations & Panel & Panel & Panel & Panel & Panel & Panel & OLS \\
\hline Variables & IP Growth & IP Growth & $\begin{array}{c}\text { IP } \\
\text { Growth }\end{array}$ & IP Growth & IP Growth & IP Growth & CRB Commodity Index Growth \\
\hline \multirow[t]{2}{*}{ G7 IP Growth } & $0.425 * * *$ & $1.069 * * *$ & $0.949 * * *$ & $1.029 * * *$ & $0.810 * * *$ & $0.756 * * *$ & $0.929 * * *$ \\
\hline & 0.000 & 0.000 & 0.000 & 0.000 & 0.000 & 0.000 & 0.000 \\
\hline \multirow[t]{2}{*}{ G7 IP Growth*Late } & $0.510 * * *$ & $-0.327 * * *$ & $-0.296 * * *$ & $-0.290 * * *$ & 0.000 & 0.015 & \\
\hline & 0.000 & 0.000 & 0.001 & 0.000 & 0.997 & 0.845 & \\
\hline \multirow[t]{2}{*}{ China IP Growth } & & $0.308 * * *$ & $0.213 * * *$ & & $-0.118 * * *$ & $-0.159 * * *$ & $1.909 * * *$ \\
\hline & & 0.000 & 0.000 & & 0.000 & 0.000 & 0.000 \\
\hline \multirow[t]{2}{*}{ China IP Growth*Late } & & $0.211 * * *$ & $0.148 * * *$ & & -0.072 & $-0.100 * * *$ & \\
\hline & & 0.000 & 0.000 & & 0.000 & 0.000 & \\
\hline \multirow[t]{2}{*}{ CRB Commodity Index Growth } & & & $0.077 * * *$ & & & $0.034 * * *$ & \\
\hline & & & 0.000 & & & 0.010 & \\
\hline \multirow[t]{2}{*}{ Constant } & $0.031 * * *$ & $-0.034 * * *$ & $-0.018 * * *$ & $0.008 * * *$ & $0.032 * * *$ & $0.039 * * *$ & $-0.227 * * *$ \\
\hline & 0.000 & 0.000 & 0.003 & 0.000 & 0.000 & 0.000 & 0.000 \\
\hline Observations & 4360 & 4360 & 4360 & 2661 & 2661 & 2661 & 212 \\
\hline R-squared & 0.350 & 0.384 & 0.388 & 0.465 & 0.472 & 0.473 & 0.552 \\
\hline \multirow[t]{2}{*}{ G7 Growth+G7 Growth*Late } & $0.935^{* * *}$ & $0.742 * * *$ & $0.653 * * *$ & $0.739 * * *$ & $0.810 * * *$ & $0.771 * * *$ & \\
\hline & 0.000 & 0.000 & 0.000 & 0.000 & 0.000 & 0.000 & \\
\hline \multirow[t]{2}{*}{ China Growth+China Growth*Late } & & $0.519 * * *$ & $0.361 * * *$ & & $-0.190 * * *$ & $-0.259 * * *$ & \\
\hline & & 0.000 & 0.000 & & 0.000 & 0.000 & \\
\hline
\end{tabular}


Table 5

EM/AM assets and their sensitivity to global factors

Note: This table presents correlation coefficients of the PC1 of EM/AM Equity/Spreads/FX against global assets for three periods during the 2000s. Source: Bloomberg, MSCI, GEM World Bank, US Treasury.

\begin{tabular}{|c|c|c|c|c|}
\hline $\begin{array}{c}\text { Country Group- } \\
\text { Asset } \\
\end{array}$ & Period & S\&P & US HY & $\begin{array}{c}\text { Broad Dollar } \\
\text { Index }\end{array}$ \\
\hline \multirow{3}{*}{ PC1-EM-Equity } & $2000-2004$ & 0.723 & -0.654 & -0.358 \\
\hline & 2005-2008M02 & 0.677 & -0.504 & -0.007 \\
\hline & 2005-2010 & 0.826 & -0.694 & -0.584 \\
\hline \multirow{3}{*}{ PC1-EM-Spreads } & $2000-2004$ & -0.396 & 0.660 & 0.451 \\
\hline & 2005-2008M02 & -0.576 & 0.739 & 0.039 \\
\hline & 2005-2010 & -0.572 & 0.767 & 0.589 \\
\hline \multirow{3}{*}{$P C 1-E M-F X$} & $2000-2004$ & -0.453 & 0.427 & 0.610 \\
\hline & 2005-2008M02 & 0.890 & 0.235 & -0.497 \\
\hline & 2005-2010 & -0.740 & 0.499 & 0.770 \\
\hline \multirow{3}{*}{ PC1-AM-Equity } & $2000-2004$ & 0.888 & -0.608 & -0.063 \\
\hline & 2005-2008M02 & 0.029 & 0.017 & 0.676 \\
\hline & $2005-2010$ & 0.890 & -0.751 & -0.497 \\
\hline \multirow{3}{*}{$P C 1-A M-F X$} & $2000-2004$ & -0.134 & 0.085 & 0.584 \\
\hline & 2005-2008M02 & -0.602 & 0.406 & 0.748 \\
\hline & 2005-2010 & -0.602 & 0.406 & 0.748 \\
\hline
\end{tabular}


Table 6

Asset betas during the 2000s in EM and AM

This table presents betas from country-by-country estimations of d $\log$ (EM Asset) vs dlog(Global Asset) during the 2000s. EM assets are MSCI country indexes, exchange rates and EM sovereign credit spreads. Global assets are the S\&P, the Broad Dollar Index and the US HY corporate spread. Dlog changes were estimated at different frequencies. For numbers in bold, t-test for means were performed. The hypothesis is that betas from the late period were lower than betas from the early period. ***, and *** denotes significane at the 10, 5 and 1\% level. Source: Bloomberg, MSCI, GEM World Bank, US Treasury.

\begin{tabular}{|c|c|c|c|c|c|c|c|c|c|c|}
\hline \multirow{2}{*}{$\begin{array}{c}\text { Country } \\
\text { Group/Statistic }\end{array}$} & \multirow{2}{*}{ Period } & \multicolumn{3}{|c|}{ Equity } & \multicolumn{3}{|c|}{ Spreads } & \multicolumn{3}{|c|}{ FX } \\
\hline & & Monthly & Quarterly & Annual & Monthly & Quarterly & Annual & Monthly & Quarterly & Annual \\
\hline \multirow{3}{*}{ Mean-EM } & $2000-2004$ & 0.761 & 0.952 & 1.071 & 0.552 & 0.743 & 0.544 & 0.654 & 0.916 & 1.181 \\
\hline & 2005-2008M02 & $1.229 * * *$ & $1.281 * * *$ & 0.721 & 0.618 & 0.793 & $0.836 * *$ & 0.618 & 0.931 & 1.052 \\
\hline & $2005-2010$ & $1.023 * * *$ & $1.159 * * *$ & $1.281 * *$ & $0.803 * * *$ & $0.973 * *$ & $0.994 * * *$ & $1.245 * * *$ & $1.403 * * *$ & 1.484 \\
\hline \multirow{3}{*}{ Median-EM } & $2000-2004$ & 0.766 & 0.976 & 1.021 & 0.553 & 0.784 & 0.567 & 0.632 & 0.858 & 0.896 \\
\hline & 2005-2008M02 & 1.223 & 1.312 & 0.645 & 0.581 & 0.712 & 0.792 & 0.550 & 0.843 & 0.991 \\
\hline & 2005-2010 & 1.041 & 1.163 & 1.236 & 0.786 & 0.946 & 0.967 & 1.324 & 1.500 & 1.540 \\
\hline \multirow{3}{*}{ Mean-AM } & $2000-2004$ & 1.063 & 1.001 & 1.199 & & & & 1.269 & 1.695 & 1.802 \\
\hline & 2005-2008M02 & $1.087 * * *$ & $1.277 * * *$ & 1.202 & & & & $1.437 *$ & 1.642 & $2.050 *$ \\
\hline & $2005-2010$ & 0.941 & 1.036 & 1.216 & & & & 1.433 & 1.512 & 1.516 \\
\hline \multirow{3}{*}{ Median-AM } & $2000-2004$ & 0.834 & 0.971 & 1.077 & & & & 1.269 & 1.752 & 1.673 \\
\hline & 2005-2008M02 & 1.063 & 1.271 & 1.199 & & & & 1.407 & 1.595 & 2.249 \\
\hline & 2005-2010 & 0.938 & 0.993 & 1.141 & & & & 1.570 & 1.564 & 1.591 \\
\hline
\end{tabular}




\section{Table 7}

The financial recoupling hypothesis

This table presents panel estimations of monthly dlog(EM Asset) vs d $\log$ (Global Asset) during the 2000s. EM assets are MSCI country indexes, exchange rates and EM sovereign credit spreads. Global assets are the S\&P, the Broad Dollar Index and the US HY corporate spread. Late is a dummy indicating the 2005-2010 period. 2000-2010 (w/o Crisis) indicates that the period during 2008M03-2009M03 were not including in the estimations. All estimations include country fixed effects. ${ }^{* * *}$, and ${ }^{* * *}$ denotes significane at the 10, 5 and 1\% level. Source: Bloomberg, MSCI, GEM World Bank, US Treasury.

\begin{tabular}{|c|c|c|c|c|c|c|}
\hline Period & $2000-2010$ & $\begin{array}{c}2000-2010 \\
\text { (w/o_Crisis) }\end{array}$ & $2000-2010$ & $\begin{array}{c}2000-2010 \\
\text { (w/o Crisis) }\end{array}$ & $2000-2010$ & $\begin{array}{l}2000-2010 \\
\text { ww/o_risisis }\end{array}$ \\
\hline Group Country & EM & EM & EM & EM & EM & EM \\
\hline Variable & Equity & Equity & Spreads & Spreads & $\mathbf{F X}$ & $\mathbf{F X}$ \\
\hline $\mathrm{S} \& \mathrm{P}$ & $\begin{array}{l}0.763 * * * \\
(0.0479)\end{array}$ & $\begin{array}{l}0.765 * * * \\
(0.0481)\end{array}$ & & & & \\
\hline S\&P*Late & $\begin{array}{c}0.260 * * * \\
(0.0650)\end{array}$ & $\begin{array}{l}0.157 * * \\
(0.0645)\end{array}$ & & & & \\
\hline US HY & & & $\begin{array}{c}0.555^{* * * *} \\
(0.0428)\end{array}$ & $\begin{array}{c}0.550 * * * \\
(0.0876)\end{array}$ & & \\
\hline US HY*Late & & & $\begin{array}{c}0.250 * * * \\
(0.0625)\end{array}$ & $\begin{array}{l}0.130 * * \\
(0.0623)\end{array}$ & & \\
\hline Broad Dollar Index & & & & & $\begin{array}{c}0.648 * * * \\
(0.0876)\end{array}$ & $\begin{array}{c}0.640 * * * \\
(0.0876)\end{array}$ \\
\hline Broad Dollar Index*Late & & & & & $\begin{array}{c}0.601 * * * \\
(0.125)\end{array}$ & $\begin{array}{c}0.314 * * * \\
(0.120)\end{array}$ \\
\hline Constant & $\begin{array}{c}0.00927 * * * \\
(0.00127)\end{array}$ & $\begin{array}{c}0.0110 * * * \\
(0.00135)\end{array}$ & $\begin{array}{c}-0.00607 * * \\
(0.00256)\end{array}$ & $\begin{array}{c}-0.00967 * * * \\
(0.00265)\end{array}$ & $\begin{array}{c}0.00119 * \\
(0.000639)\end{array}$ & $\begin{array}{c}0.000244 \\
(0.000628)\end{array}$ \\
\hline Observations & 3036 & 2737 & 2112 & 1904 & 2508 & 2261 \\
\hline R-squared & 0.289 & 0.215 & 0.281 & 0.195 & 0.175 & 0.097 \\
\hline
\end{tabular}


Table 8

Correlation between TIC and EPFR data

This table presents country correlations between capital inflows measures from TIC and EPFR data. TIC data is the absolute value of monthly inflows (purchases minus sales from US residents in a country) normalized by equity market capitalization or total debt. EPFR data if the absolute value of monthly inflows into a country by global equity/debt funds normalized by market capitalization or total debt. * denotes significance at the $1 \%$ level. Source: EPFR, Bloomberg, US Treasury, BIS.

\begin{tabular}{cccc} 
Country & $\begin{array}{c}\text { Equity EPFR/TIC } \\
\text { Correlation }\end{array}$ & Country & $\begin{array}{c}\text { Bond EPFR/TIC } \\
\text { Correlation }\end{array}$ \\
\hline \hline Argentina & $0.4422^{*}$ & Argentina & 0.2211 \\
Brazil & 0.1846 & Brazil & -0.0704 \\
Chile & -0.03 & Chile & 0.0922 \\
China & 0.1475 & China & -0.1972 \\
Czech Republic & -0.0691 & Hungary & 0.1152 \\
Egypt & -0.0892 & Indonesia & -0.1646 \\
Hungary & 0.1475 & Poland & 0.1454 \\
India & 0.0839 & Mexico & 0.2493 \\
Indonesia & -0.0055 & Peru & -0.0794 \\
Israel & 0.2089 & Philippines & 0.0269 \\
Korea & 0.2517 & Poland & 0.0964 \\
Malaysia & 0.3057 & Russia & -0.1464 \\
Mexico & 0.0716 & South Africa & 0.0873 \\
Peru & 0.2878 & Turkey & 0.1249 \\
Philippines & 0.1398 & Venezuela & -0.0861 \\
Poland & -0.0241 & & \\
Russia & 0.0383 & & \\
South Africa & 0.1092 & & \\
Taiwan & 0.0776 & & \\
Thailand & $0.4421 *$ & & \\
Turkey & -0.0961 & & \\
\hline \hline
\end{tabular}


Table 9

Financial globalization and financial recoupling around the crisis

This table presents stress tests to estimations in Didier et al., 2010. First three columns presents data from Didier et al., and their methodology. Returns are normal local returns, are filtered leaving outliers out, and US Holdings are normalized by substracting its sample average and dividing it by its sample standard deviation. Additionally their crisis period are defined as 6/2007 to 4/2009 as opposed to the 03/2008-03/2009 crisis period used in this paper. In turn, columns 4-10 are presented for the same data but with our methodology. Returns are dlog(stock_index) and does not filter any local stock market returns. *,**,** Denote significance at the $1 \%, 5 \%$, and $10 \%$ levels, respectively. In italics appears the correspondent the p-value. Source: Didier et al,. 2010, Bloomberg, US Treasury.

\begin{tabular}{|c|c|c|c|c|c|c|c|c|c|}
\hline Type of estimation & \multicolumn{3}{|c|}{ Time dummies, Lehman interaction } & \multicolumn{6}{|c|}{ Replacing time dummies by $S \& P$ returns } \\
\hline Variable/Sample & $\begin{array}{l}\text { Full Sample } \\
\text { (Didier et al., } \\
2010) \\
\end{array}$ & EM+Developed & $\begin{array}{c}\text { Non-EM } \\
\text { developing }\end{array}$ & $\begin{array}{c}\text { Full } \\
\text { Sample }\end{array}$ & $\begin{array}{c}\text { Full } \\
\text { Sample }\end{array}$ & EM+Developed & $\begin{array}{c}\text { Non-EM } \\
\text { developing }\end{array}$ & EM & EM \\
\hline S\&P returns*US Holdings*Pre- & $0.2783 * * *$ & -0.002 & $0.4869 * * *$ & $0.0141 *$ & & & & & \\
\hline Lehman & 0.000 & 0.983 & 0.001 & 0.068 & & & & & \\
\hline S\&P returns*US Holdings*Post- & $0.2149 * * *$ & 0.072 & $0.3234 * * *$ & 0.0113 & & & & & \\
\hline Lehman & 0.000 & 0.397 & 0.018 & 0.106 & & & & & \\
\hline S\&P return $*$ U IS Holdinos & & & & & $0.012 *$ & -0.004 & $0.0382 * *$ & -0.019 & \\
\hline Sor Teturns US Hoidings & & & & & 0.091 & 0.617 & 0.027 & 0.192 & \\
\hline S\&P Returns*US Absolute & & & & & & & & & 0.330 \\
\hline & & & & & & & & & 0.320 \\
\hline US Absolute Flows & & & & & & & & & 0.040 \\
\hline & & & & & & & & & 0.427 \\
\hline S\&P returns & & & & $0.8549 * * *$ & $0.8549 * * *$ & $1.080 * * *$ & 0.7516 *** & $1.201 * * *$ & $1.008 * * *$ \\
\hline Sor tetumins & & & & 0.000 & 0.000 & 0.000 & 0.000 & 0.000 & 0.000 \\
\hline R-squared & 0.558 & 0.682 & 0.467 & 0.347 & 0.347 & 0.554 & 0.274 & 0.504 & 0.501 \\
\hline Observations & 1539 & 651 & 802 & 1628 & 1628 & 682 & 858 & 273 & 273 \\
\hline Time dummies & Yes & Yes & Yes & No & No & No & No & No & No \\
\hline Countries & 74 & 31 & 39 & 74 & 74 & 31 & 39 & 21 & 21 \\
\hline
\end{tabular}


Table 10

FG and financial recoupling: EPFR Flow Data

This table presents estimations of the relationship between financial recoupling and financial globalization. All results are from panel estimations with country fixed effects. FG Flows are absolute values of net inflows to a country by global and global emerging mutual funds normalized by market capitalization. Dependent variables are dlog returns from EM assets (MSCI country indexes, sovereign spreads, and exchange rate, LCU/USD). Sample goes from 2005-09/2010 due to data availability. Normal and turmoil divides the sample between positive (or zero) and negative returns from the global asset respectively. Robust standard errors in parentheses. *, **, and *** denotes significance at the 10, 5 and $1 \%$ level respectively. Source: MSCI, GEM World Bank, Bloomberg, US Treasury, EPFR, Barclays Capital, GEM World Bank, IMF IFS Statistics.

\begin{tabular}{|c|c|c|c|}
\hline Sample & Full Sample & Turmoil & Normal \\
\hline \multicolumn{4}{|c|}{$\begin{array}{c}\text { Equity } \\
\end{array}$} \\
\hline S\&P Returns & $\begin{array}{c}0.586 * * * \\
(0.058)\end{array}$ & $\begin{array}{c}0.579 * * * \\
(0.119)\end{array}$ & $\begin{array}{c}0.841 * * * \\
(0.137)\end{array}$ \\
\hline S\&P Returns*FG Flow & $\begin{array}{c}4.204^{* * *} \\
(0.412)\end{array}$ & $\begin{array}{c}4.879 * * * \\
(0.787)\end{array}$ & $\begin{array}{c}0.739 \\
(0.967)\end{array}$ \\
\hline FG Flow & $\begin{array}{c}0.021 \\
4.204 * * *\end{array}$ & $\begin{array}{c}0.060 \\
(0.054)\end{array}$ & $\begin{array}{c}0.094 * * * \\
(0.029)\end{array}$ \\
\hline Observations & 1,449 & 588 & 861 \\
\hline R-Squared & 0.457 & 0.427 & 0.201 \\
\hline Countries & 21 & 21 & 21 \\
\hline \multicolumn{4}{|c|}{ Bond } \\
\hline US HY Returns & $\begin{array}{c}0.618 * * * \\
(0.0457)\end{array}$ & $\begin{array}{c}0.618 * * * \\
(0.0690)\end{array}$ & $\begin{array}{c}0.425 * * * \\
(0.147)\end{array}$ \\
\hline US HY Returns*FG Flow & $\begin{array}{c}2.638 * * * \\
(0.305)\end{array}$ & $\begin{array}{c}3.455 * * * \\
(0.559)\end{array}$ & $\begin{array}{l}-0.153 \\
(1.650)\end{array}$ \\
\hline FG Flow & $\begin{array}{l}-0.134 * \\
(0.0691)\end{array}$ & $\begin{array}{c}-0.376^{* *} \\
(0.159)\end{array}$ & $\begin{array}{c}-0.297 * * \\
(0.122)\end{array}$ \\
\hline Observations & 1005 & 495 & 510 \\
\hline R-Squared & 0.402 & 0.459 & 0.060 \\
\hline Countries & 15 & 15 & 15 \\
\hline \multicolumn{4}{|c|}{ FX } \\
\hline Broad Dollar Index Returns & $\begin{array}{c}1.251 * * * \\
(0.113)\end{array}$ & $\begin{array}{c}1.514 * * * \\
(0.218)\end{array}$ & $\begin{array}{c}0.665^{* * *} * \\
(0.216)\end{array}$ \\
\hline Broad Dollar Index*FG Flow & $\begin{array}{c}1.610 \\
(1.452)\end{array}$ & $\begin{array}{l}4.568 * \\
(2.442)\end{array}$ & $\begin{array}{c}0.762 \\
(2.724)\end{array}$ \\
\hline FG Flow & $\begin{array}{l}-0.0209 \\
(0.0260)\end{array}$ & $\begin{array}{c}-0.0875 * * \\
(0.0391)\end{array}$ & $\begin{array}{l}-0.0432 \\
(0.0364)\end{array}$ \\
\hline Observations & 1,173 & 510 & 663 \\
\hline R-Squared & 0.287 & 0.368 & 0.076 \\
\hline Countries & 17 & 17 & 17 \\
\hline
\end{tabular}




\section{Table 11}

\section{FG and financial recoupling: Robustness tests and causality}

This table presents estimations of the relationship between financial recoupling and financial globalization. All results are from Arellano and Bond difference estimator. FG Flows are absolute values of net inflows to a country by global and global emerging mutual funds normalized by market capitalization. Dependent variables are dlog returns from EM assets (MSCI country indexes, sovereign spreads, and exchange rate, LCU/USD). Sample goes from 2005-09/2010 due to data availability. Normal and turmoil divides the sample between positive (or zero) and negative returns from the global asset respectively. Different type of instruments were used. External indicates that instruments for country $\mathrm{i}$ were FG flows to EM minus FG flows to country i. Internal indicates that the first lag of the dependent variables were used as instruments. Robust standard errors in parentheses. *,**, and *** denotes significance at the 10, 5 and $1 \%$ level respectively. Source: MSCI, GEM World Bank, Bloomberg, US Treasury, EPFR, Barclays Capital, GEM World Bank, IMF IFS Statistics.

\begin{tabular}{|c|c|c|c|c|c|c|}
\hline Sample & Full Sample & Turmoil & Normal & Full Sample & Turmoil & Normal \\
\hline Instrument Type & External & External & External & Internal & Internal & Internal \\
\hline \multicolumn{7}{|c|}{ Equity } \\
\hline S\&P Returns & $\begin{array}{c}0.255^{* * *} \\
(0.089)\end{array}$ & $\begin{array}{c}0.047 \\
(0.140)\end{array}$ & $\begin{array}{c}0.503 * * * \\
(0.103)\end{array}$ & $\begin{array}{c}0.474 * * * \\
(0.090)\end{array}$ & $\begin{array}{c}0.432 * * * \\
(0.113)\end{array}$ & $\begin{array}{c}0.564 * * * \\
(0.129)\end{array}$ \\
\hline S\&P Returns*FG Flow & $\begin{array}{c}7.192 * * * \\
(1.020)\end{array}$ & $\begin{array}{c}8.136 * * * \\
(1.366)\end{array}$ & $\begin{array}{c}3.580 * * * \\
(0.788)\end{array}$ & $\begin{array}{c}4.596 * * * \\
(0.636)\end{array}$ & $\begin{array}{c}5.193 * * * \\
(0.765)\end{array}$ & $\begin{array}{c}2.620 * * \\
(1.155)\end{array}$ \\
\hline FG Flow & $\begin{array}{c}0.031 \\
(0.026)\end{array}$ & $\begin{array}{c}0.192 * * * \\
(0.049)\end{array}$ & $\begin{array}{c}0.046 \\
(0.041)\end{array}$ & $\begin{array}{c}0.053 * * * \\
(0.016)\end{array}$ & $\begin{array}{c}0.119 * * * \\
(0.025)\end{array}$ & $\begin{array}{c}0.017 \\
(0.034)\end{array}$ \\
\hline Observations & 1,428 & 567 & 861 & 1,428 & 567 & 861 \\
\hline \multicolumn{7}{|c|}{ Bond } \\
\hline US HY Returns & $\begin{array}{c}0.464 * * * \\
(0.0430)\end{array}$ & $\begin{array}{c}0.234 * * * \\
(0.0446)\end{array}$ & $\begin{array}{c}0.620 * * * \\
(0.166)\end{array}$ & $\begin{array}{c}0.448 * * * \\
(0.0507)\end{array}$ & $\begin{array}{c}0.400 * * * \\
(0.0546)\end{array}$ & $\begin{array}{c}0.499 * * * \\
(0.103)\end{array}$ \\
\hline US HY Returns*FG Flow & $\begin{array}{c}4.999 * * * \\
(0.956)\end{array}$ & $\begin{array}{c}8.295 * * * \\
(1.609)\end{array}$ & $\begin{array}{c}1.719 \\
(3.061)\end{array}$ & $\begin{array}{c}3.857 * * * \\
(0.783)\end{array}$ & $\begin{array}{c}4.408 * * * \\
(0.877)\end{array}$ & $\begin{array}{c}1.528 \\
(1.444)\end{array}$ \\
\hline FG Flow & $\begin{array}{c}-0.470 * * * \\
(0.165)\end{array}$ & $\begin{array}{c}-1.309 * * * \\
(0.337)\end{array}$ & $\begin{array}{c}-1.120 * * * \\
(0.378)\end{array}$ & $\begin{array}{c}-0.350 * * * \\
(0.123)\end{array}$ & $\begin{array}{c}-0.456 * * * \\
(0.171)\end{array}$ & $\begin{array}{c}-0.585^{* * *} * \\
(0.107)\end{array}$ \\
\hline Observations & 1,005 & 495 & 510 & 1,005 & 495 & 510 \\
\hline \multicolumn{7}{|c|}{$\mathbf{F X}$} \\
\hline Broad Dollar Index Returns & $\begin{array}{c}1.077 * * * \\
(0.190)\end{array}$ & $\begin{array}{c}1.094 * * * \\
(0.243)\end{array}$ & $\begin{array}{c}0.774 * * * \\
(0.199)\end{array}$ & $\begin{array}{c}1.140 * * * \\
(0.185)\end{array}$ & $\begin{array}{c}1.277 * * * \\
(0.219)\end{array}$ & $\begin{array}{c}0.859 * * * \\
(0.165)\end{array}$ \\
\hline Broad Dollar Index*FG Flow & $\begin{array}{c}5.494 \\
(3.773)\end{array}$ & $\begin{array}{c}6.055 \\
(4.760)\end{array}$ & $\begin{array}{l}-0.983 \\
(3.482)\end{array}$ & $\begin{array}{c}1.100 \\
(1.449)\end{array}$ & $\begin{array}{c}1.381 \\
(1.957)\end{array}$ & $\begin{array}{c}-1.758 \\
(1.170)\end{array}$ \\
\hline FG Flow & $\begin{array}{l}-0.0283 \\
(0.0292)\end{array}$ & $\begin{array}{c}-0.241 * * * \\
(0.0757)\end{array}$ & $\begin{array}{c}-0.0917 * * \\
(0.0434)\end{array}$ & $\begin{array}{c}-0.0624 * * \\
(0.0308)\end{array}$ & $\begin{array}{l}-0.0352 \\
(0.0442)\end{array}$ & $\begin{array}{c}-0.128 * * * * \\
(0.0242)\end{array}$ \\
\hline Observations & 1,156 & 493 & 663 & 1,156 & 493 & 663 \\
\hline
\end{tabular}


Table 12

Benchmarking in Mutual Funds

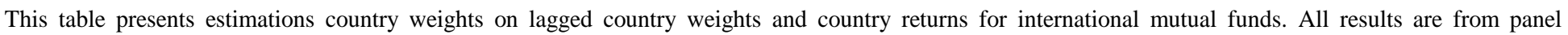

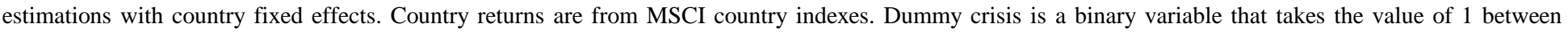

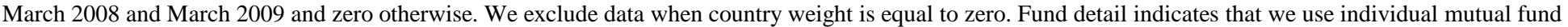

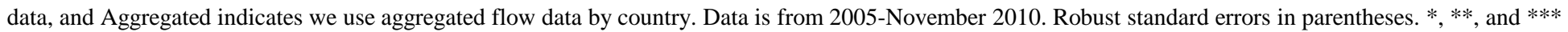

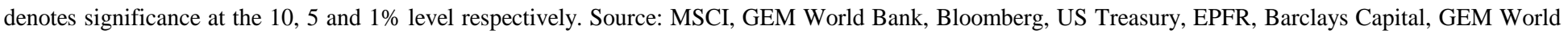
Bank, IMF IFS Statistics.

\begin{tabular}{cccccccc}
\hline \hline & & & & & & & \\
Country Weight (t-1) & $0.956^{* * *}$ & $0.956^{* * *}$ & $0.956^{* * *}$ & $0.904 * * *$ & $0.963 * * *$ & $0.96338^{* * * *}$ & $0.963 * * *$ \\
& $(0.002)$ & $(0.002)$ & $(0.002)$ & $(0.005)$ & $(0.015)$ & $(0.015)$ & $(0.016)$ \\
Country Weight (t-1)*Crisis Dummy & & -0.002 & & & & -0.00039 & $(0.008)$ \\
& & $(0.002)$ & & & & 0.00971 & 0.060 \\
Country Returns (t-1) & 0.009 & -0.010 & -0.021 & 0.061 & 0.012 & 0.00971 \\
& & $(0.047)$ & $(0.097)$ & $(0.099)$ & $(0.109)$ & $(0.100)$ & $(0.150)$ \\
Country FE & & & & & & & YES \\
Time FE & YES & YES & YES & NO & YES & YES & YES \\
Fund-Country FE & NO & NO & NO & YES & NO & NO & NO \\
Observations & & & & & & & \\
R-squared & 94,020 & 94,020 & 94,020 & 94,020 & 1,286 & 1,286 & 1,286 \\
\hline \hline
\end{tabular}


Figure 1

\section{Convergence among EM?}

This figure presents the relationship between 5-year average GDP growth forecast (2011-2015) and per capita GDP in USD in 2009 for the sample of EM used in this paper. (*) denotes significance at the 10\% level. Source: IMF WEO April 2011.

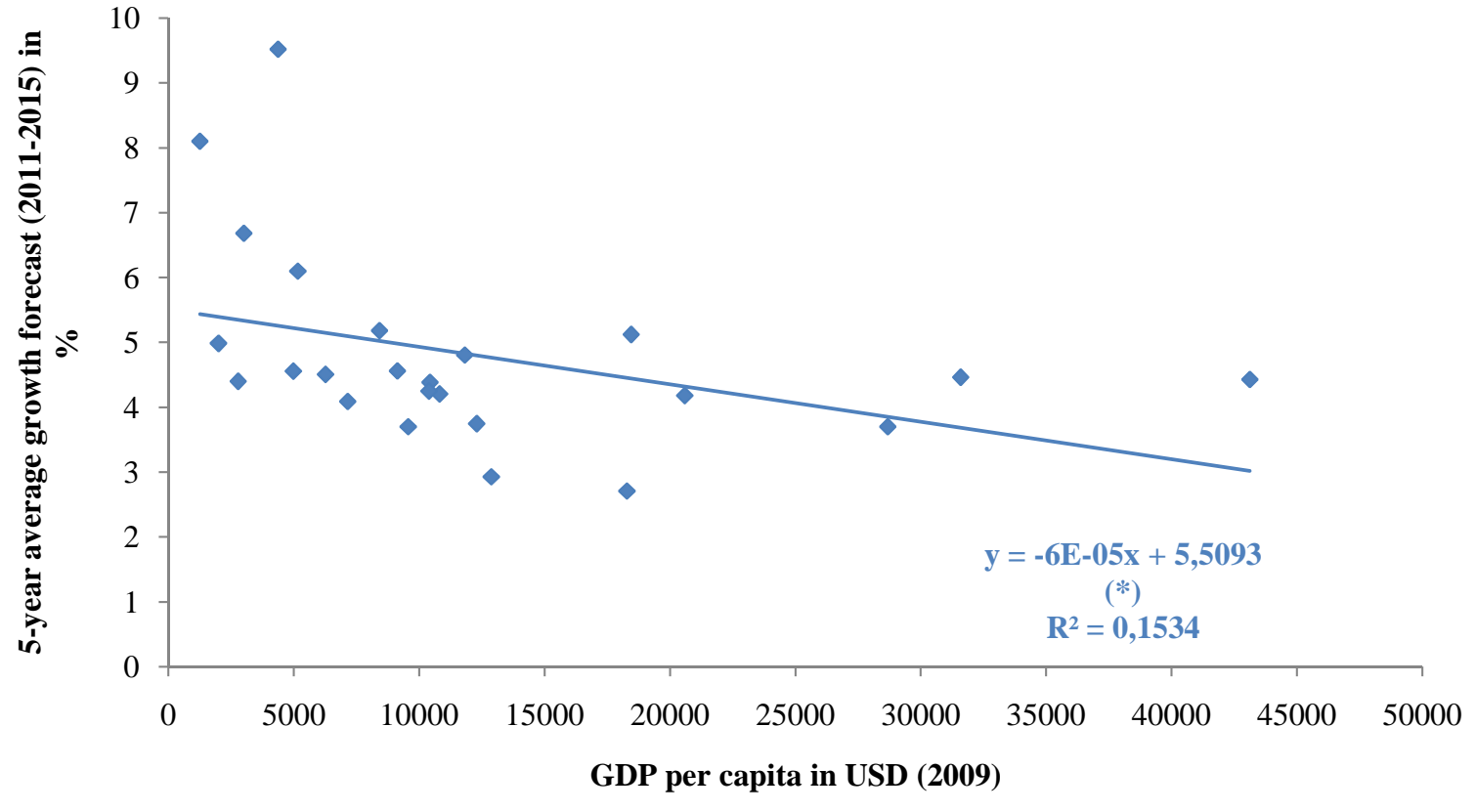


Figure 2

Coupling in the global cycle

This figure presents the median R-squared among emerging and advanced economies from regressions of growth in country i versus $\mathrm{PC} 1$ growth in these countries (as a proxy from global growth)

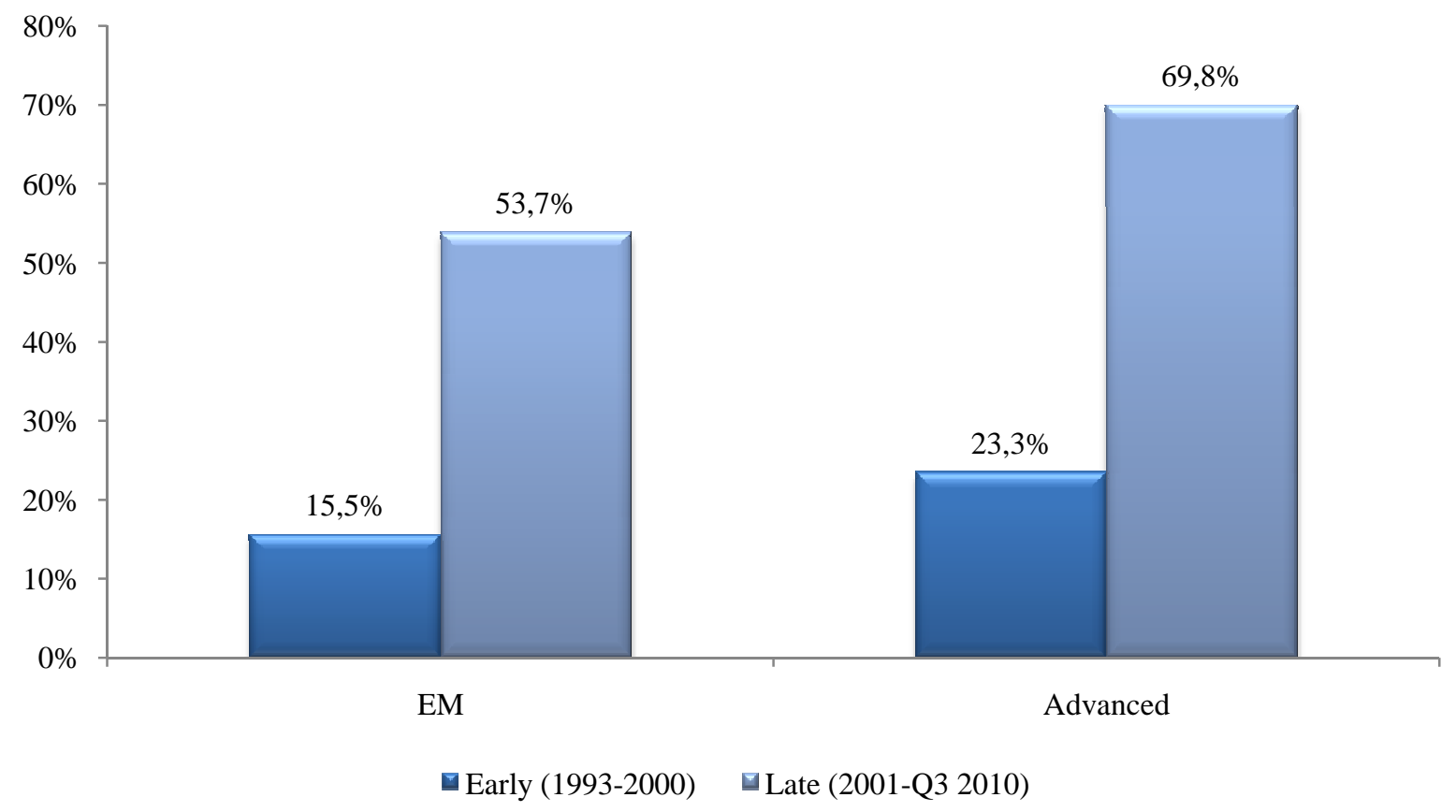




\section{Figure 3}

Seemingly growing correlation between G7 and EM's growth cycle

This figure presents average 5-year correlation between growth in EM countries and G7 growth. First, 5-year rolling correlations between individual countries and G7 were obtained, and then the simple average across emerging countries was taken. Source: IMF WEO April 2011.

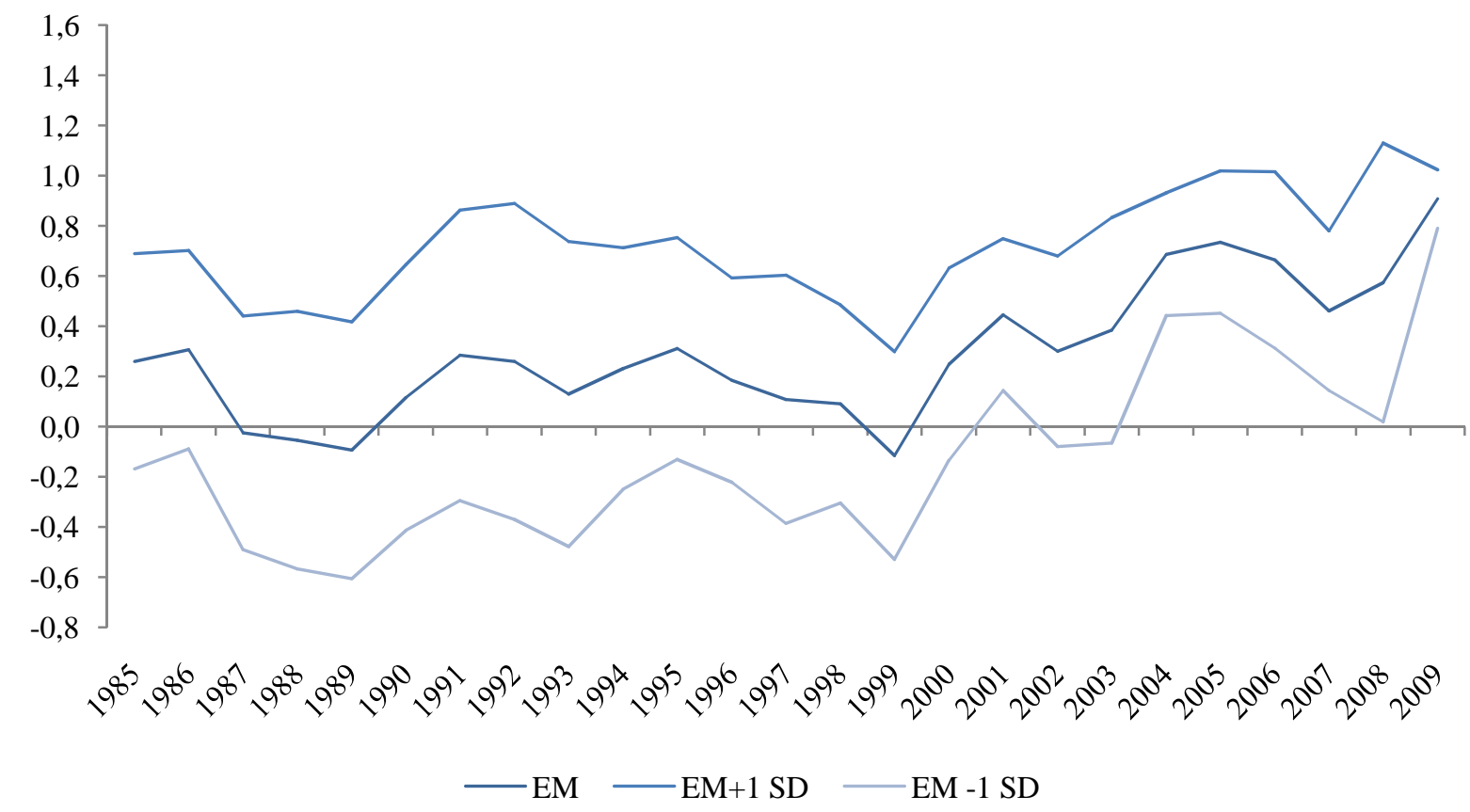




\section{Figure 4}

Growth outperformance in EM relative to G7

This figure shows EM growth and G7 growth. EM is the simple average of individual countries. Source: IMF WEO April 2011.

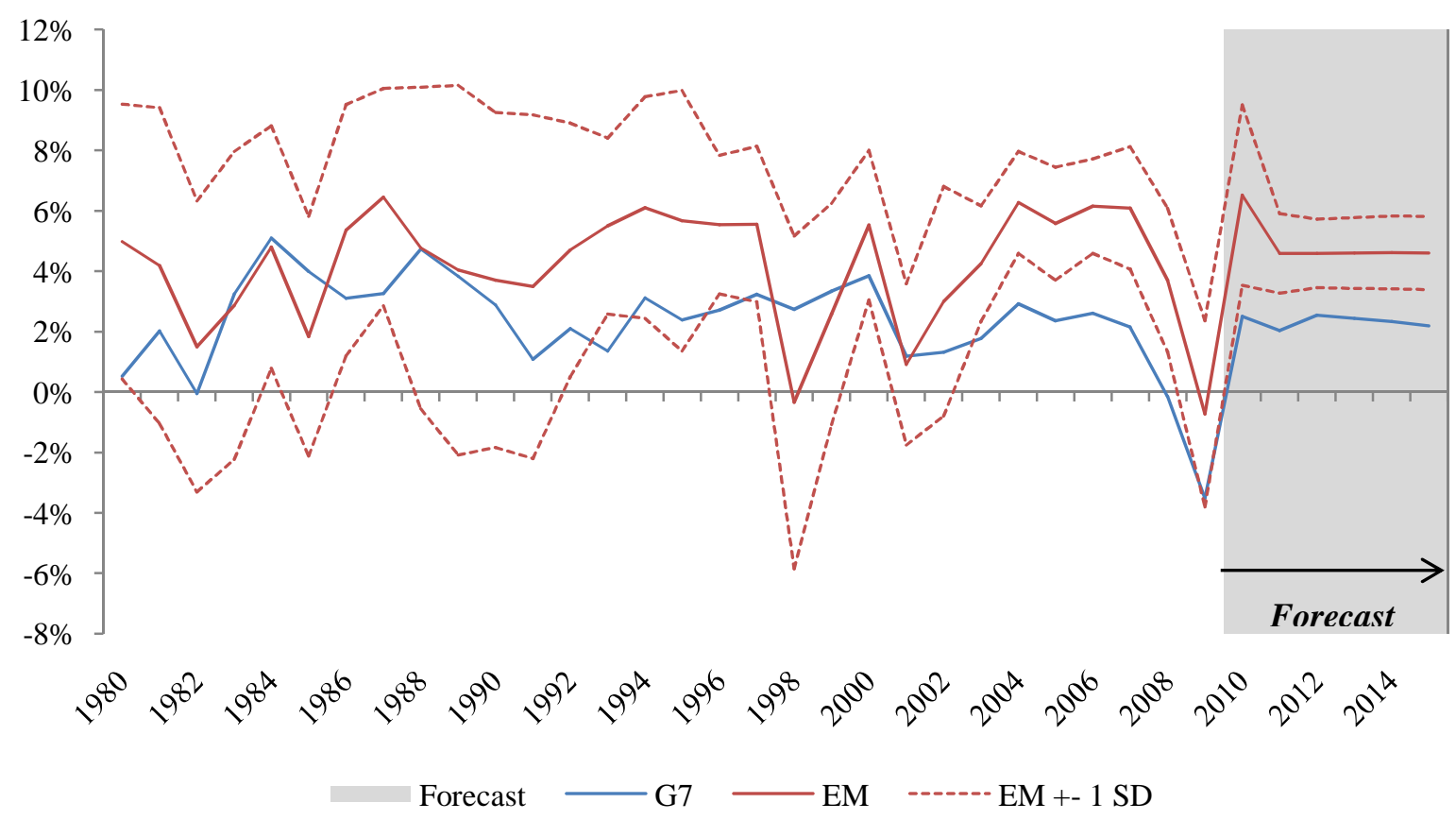




\section{Figure 5}

\section{Convergence between EM and G7: Alphas and Per capita GDP}

This figure presents alphas from estimations in column 4 in Table 3.1 for individual countries and their relationship with initial (1993) GDP per capita PPP. Source: IMF IFS Statistics, IMF WEO

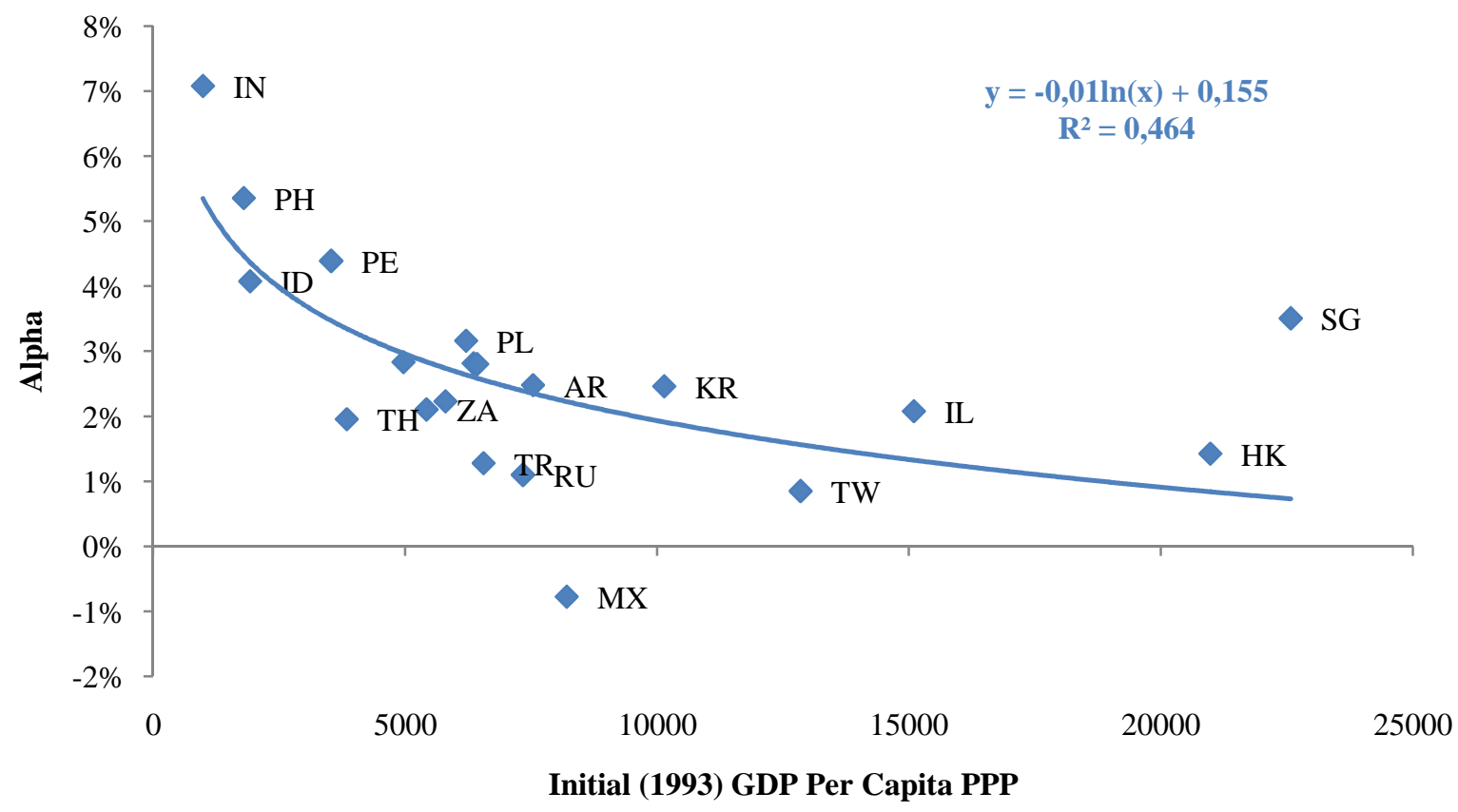




\section{Figure 6}

Real decoupling in EM: Decoupling with G7 and coupling with China

This figure presents different betas from 2003 to 09/2010. Betas for G7 and China were estimated from d $\log (\mathrm{EM})$ vs $\operatorname{d} \log (\mathrm{G} 7) \mathrm{d} \log (\mathrm{China})$, were EM, G7, and China are real gdp growth or industrial production growth in EM countries, the G7 and China respectively. Betas were estimated by extending the time window. The first betas were estimated with the sample going from 1993 to 2003, and for the rest of the betas we extended the sample until 09/2010. Source: IMF IFS, GEM World Bank.

\section{Real GDP Growth}

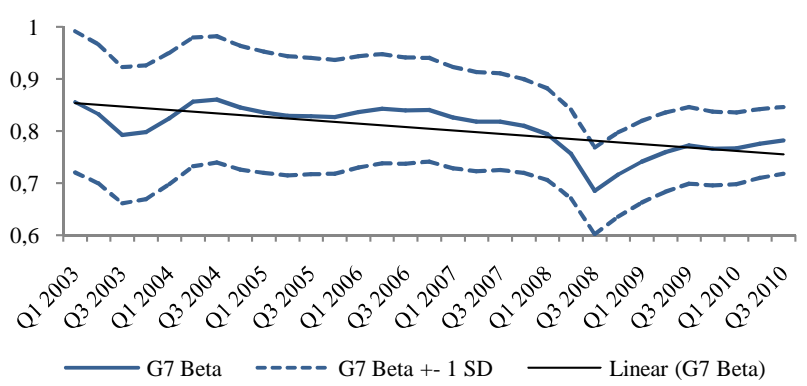

Industrial Production Growth

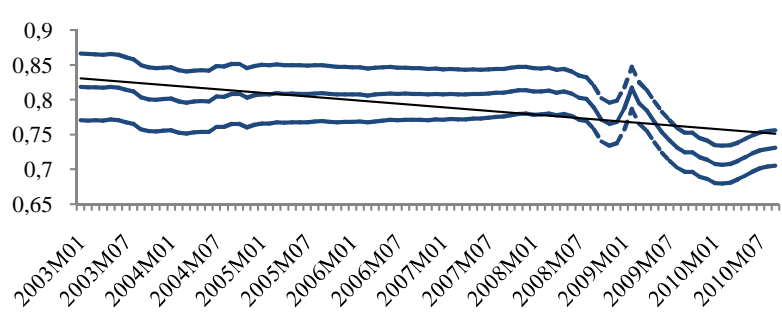

G7 Beta ----- G7 Beta +- 1 SD _ Linear (G7 Beta)
Real GDP Growth

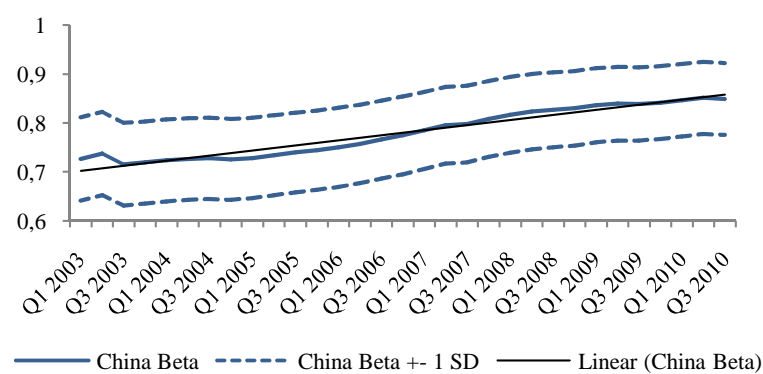

Industrial Production Growth

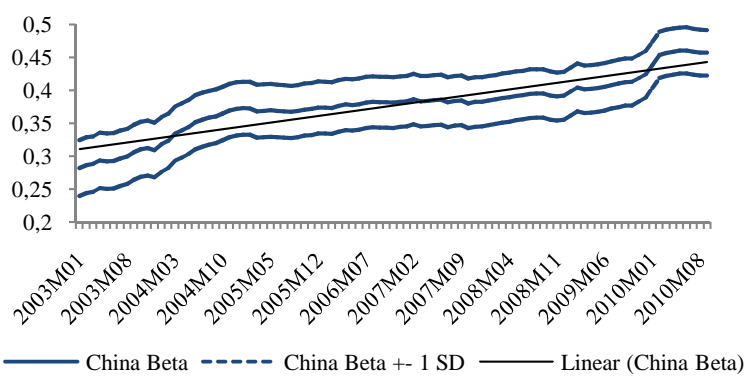


Figure 7

China as a standalone engine for growth (a)

This figure presents weights from PC1 and PC2 from principal component analysis of G8 (G7+China) growth. Growth is proxied by real GDP annual log growth $(\mathrm{q} / \mathrm{q})$ and industrial production annual log growth $(\mathrm{m} / \mathrm{m})$. Source: IMF IFS Statistics, GEM World Bank.

\section{Real GDP Growth}

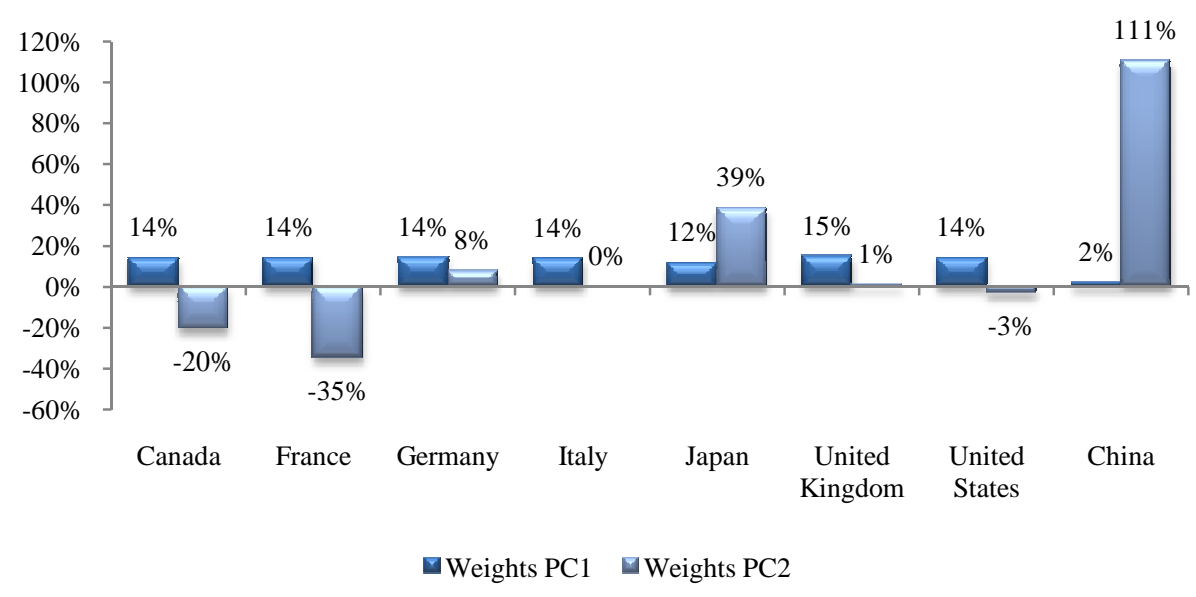

Industrial Production Growth

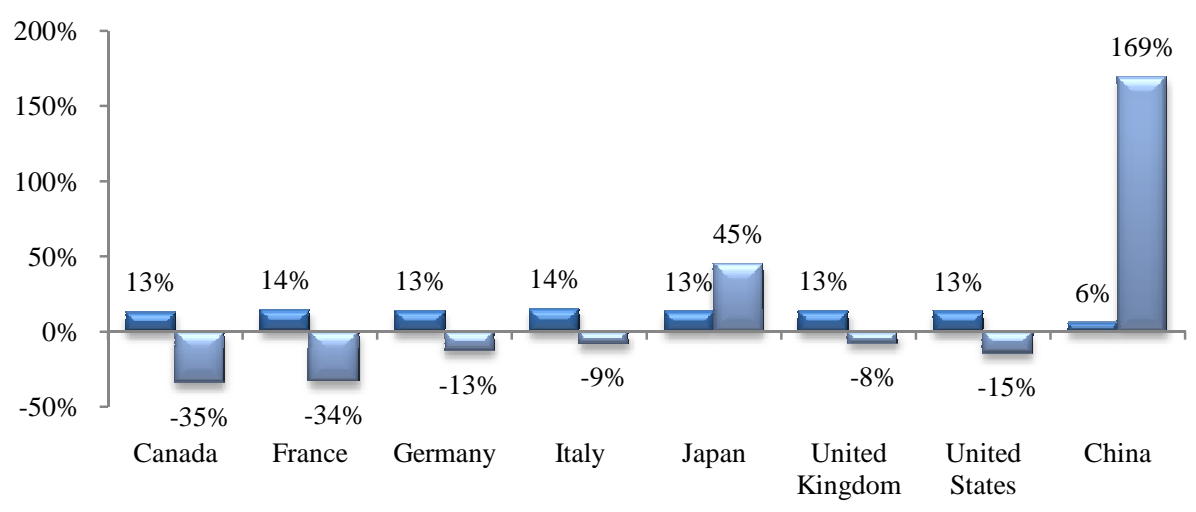

$\square$ Weights PC1 $\square$ Weights PC2 
Figure 8

China as a standalone engine for growth (b)

This figure presents R-squared from individual regressions of growth vs PC1 or PC2 from principal component analysis of G8 (G7+China) growth. Growth is proxied by real GDP annual $\log$ growth $(\mathrm{q} / \mathrm{q})$ and industrial production annual $\log$ growth $(\mathrm{m} / \mathrm{m})$. Source: IMF IFS Statistics, GEM World Bank.

\section{Real GDP Growth}

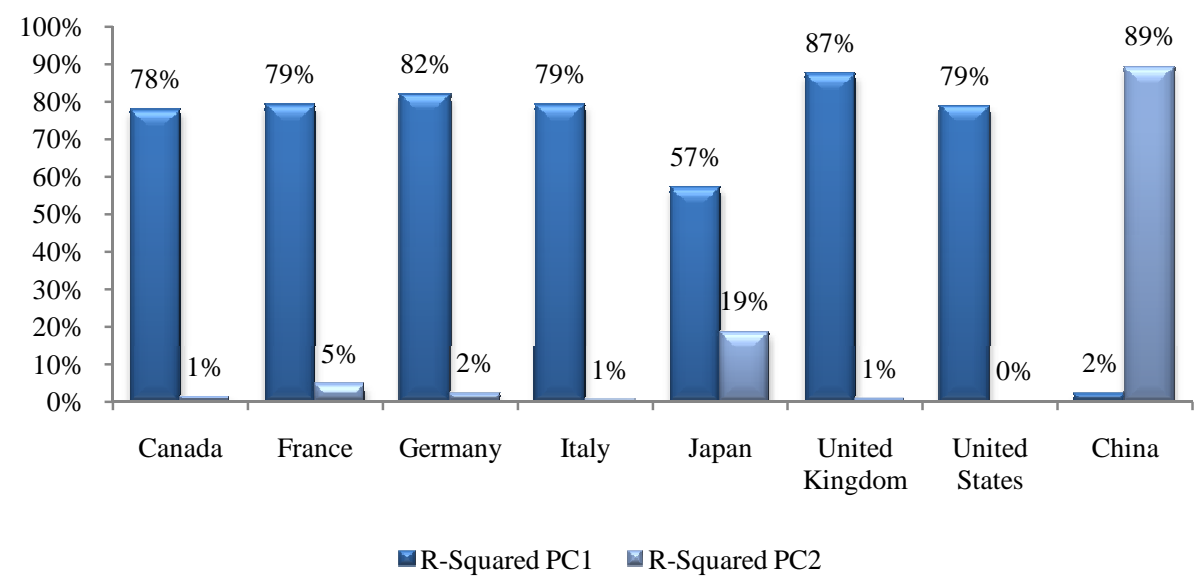

Industrial Production Growth

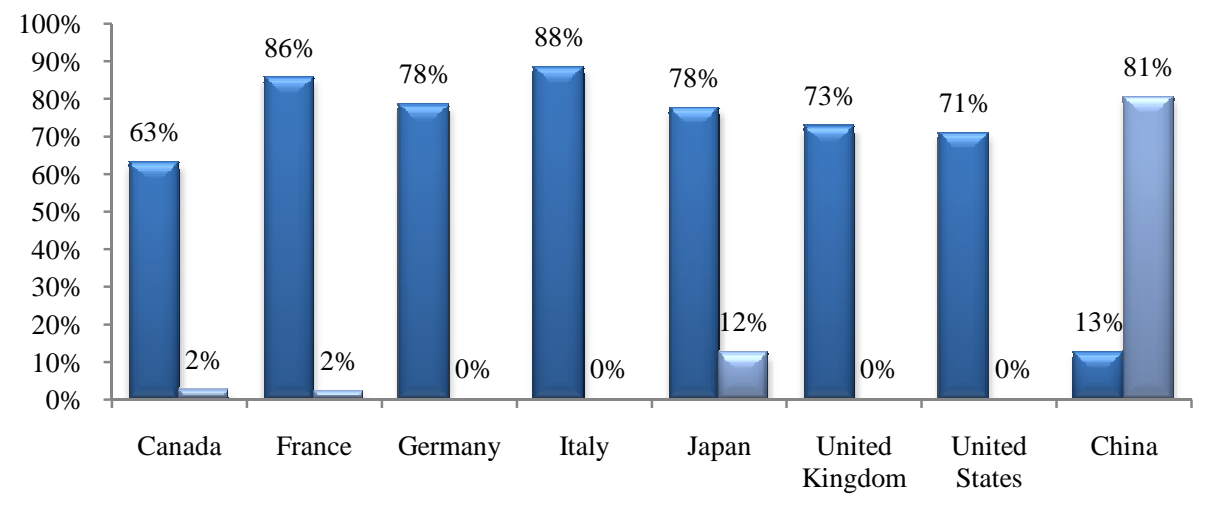

$\square \mathrm{R}-$ Squared PC1 $\square \mathrm{R}-$ Squared PC2 
Figure 9

EM Assets co-movement

This figure presents median R-squared from estimations of individual country's assets log returns (Equity/Spreads/FX) against the PC1 of the log returns in these EM. Source: Bloomberg, MSCI, GEM World Bank.

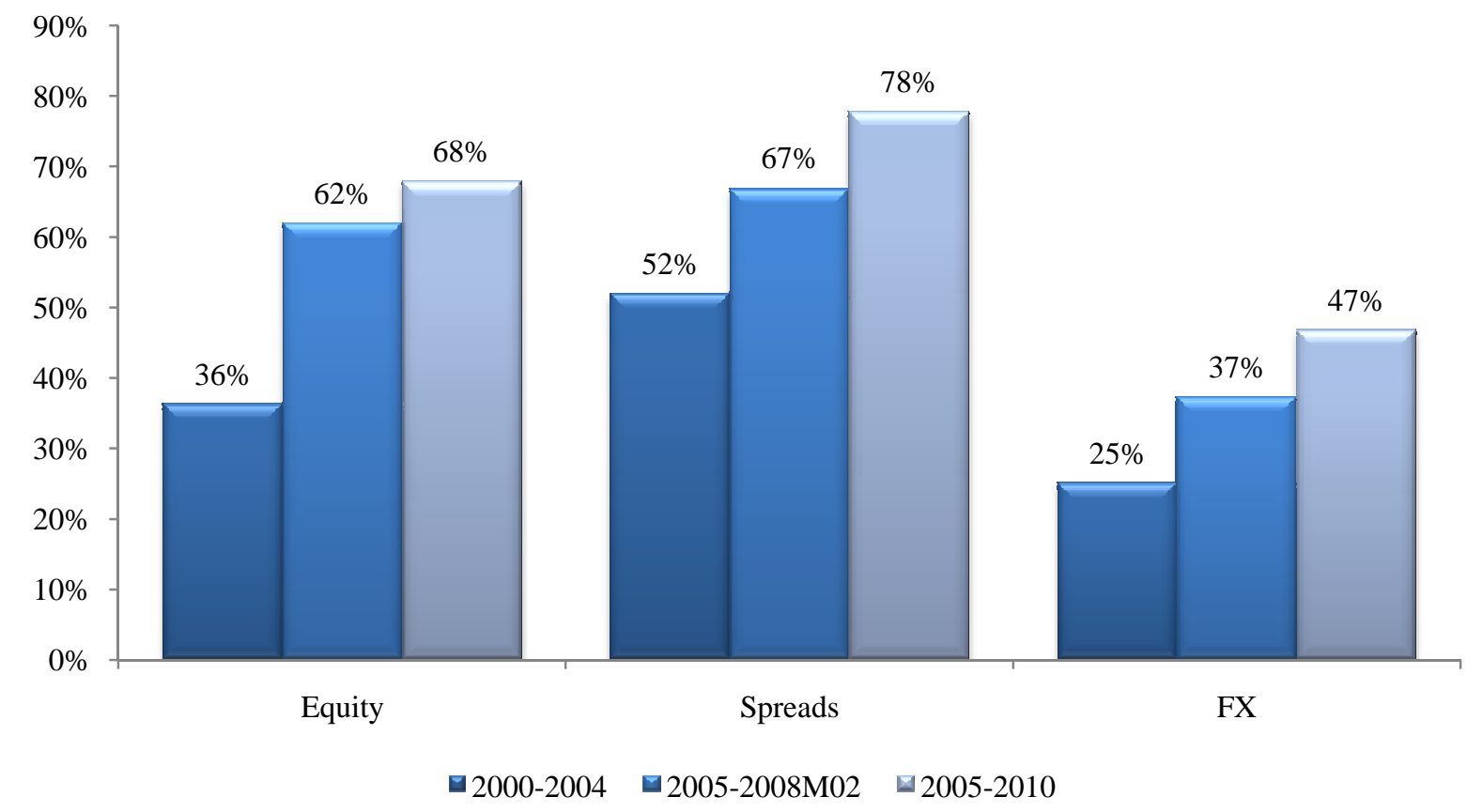


Figure 10

EM Assets' Betas during the 2000s

This figure presents betas from country-by-country estimations of dlog(EM Asset) vs dlog(Global Asset) during 2000-2004 and 2005-2010. EM assets are MSCI country indexes, exchange rates and EM sovereign credit spreads. Global assets are the S\&P, the Broad Dollar Index and the US HY corporate spread. Source: Bloomberg, MSCI, GEM World Bank, US Treasury.
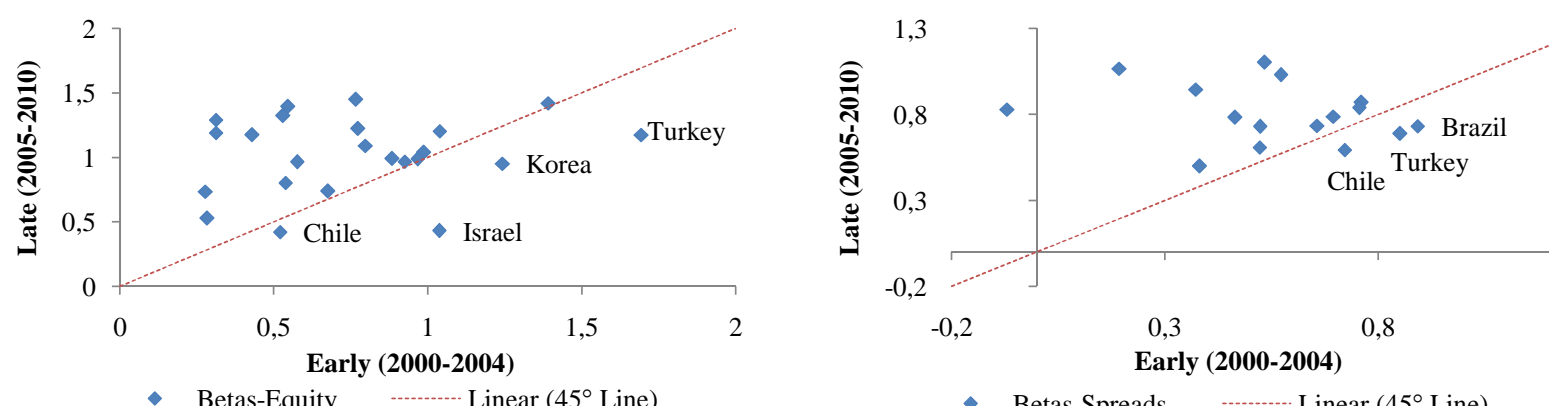

- Betas-Equity

-.- Linear $\left(45^{\circ}\right.$ Line $)$

- Betas-Spreads

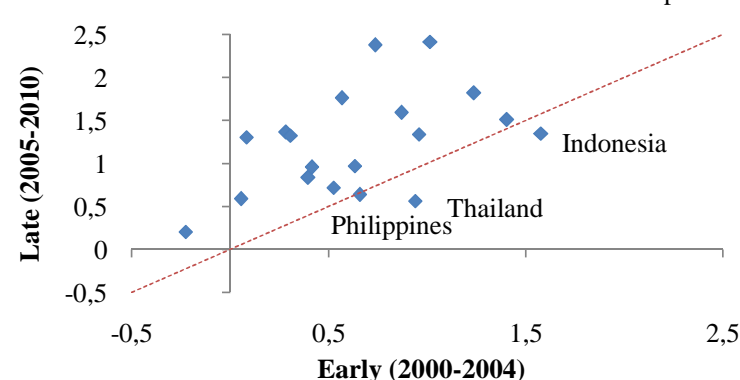

Betas-FX …--..- Linear $\left(45^{\circ}\right.$ Line $)$ 
Figure 11

Financial globalization through global equity funds

This figure presents the percentage of assets invested in Advanced and Emerging markets by global equity funds. Source: EPFR

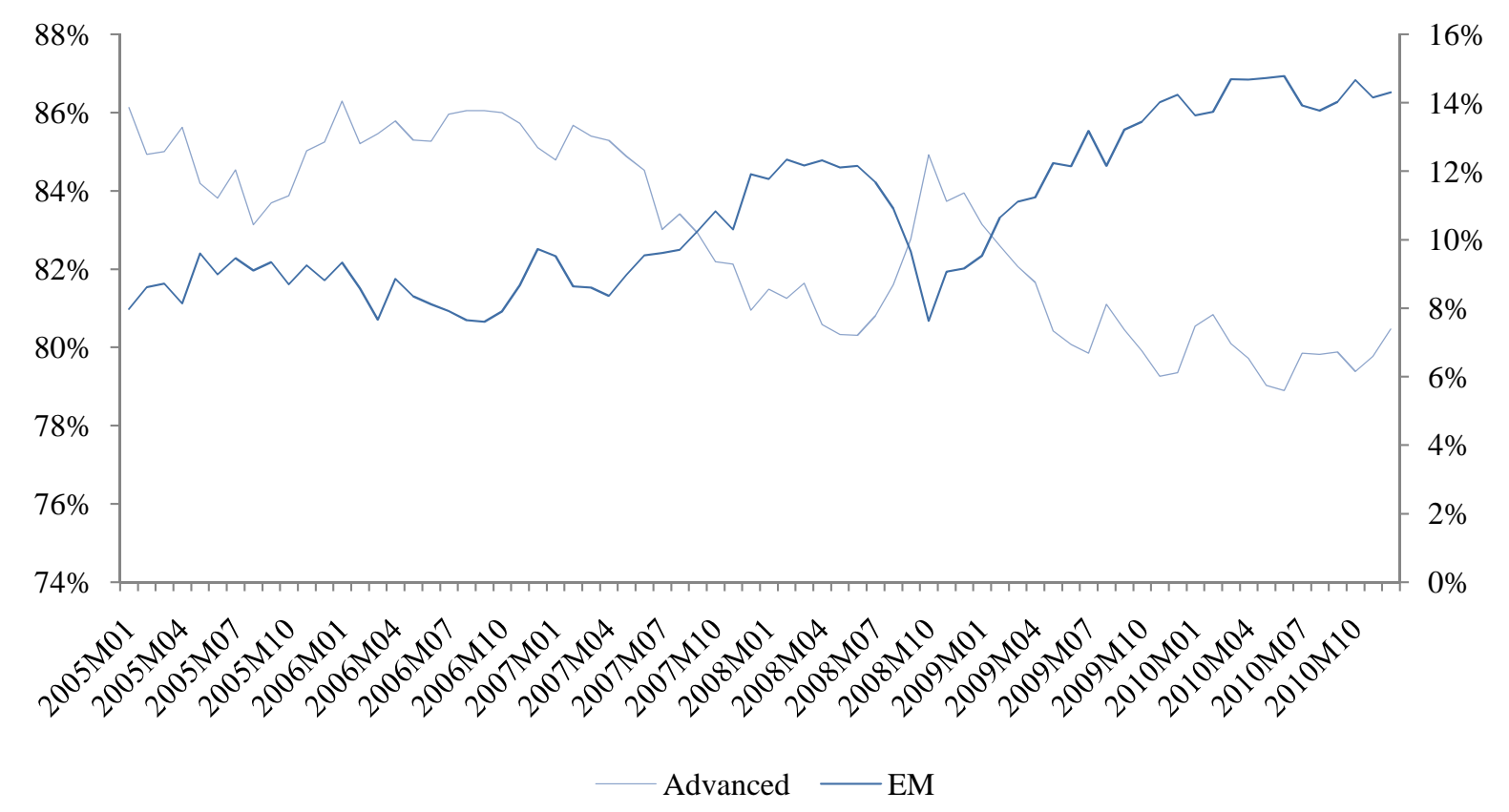


Figure 12

High alpha, high beta pattern

This figure presents $\log$ (EM Asset) and $\log$ (Global Asset) during 2005-2010. EM assets are MSCI EM, FX-EM and EMBI Global. FX-EM is an index that averages dlog changes across EM' FX. Global assets are the S\&P, the Broad Dollar Index and the US HY corporate spread. Source: Bloomberg, MSCI, GEM World Bank, US Treasury.
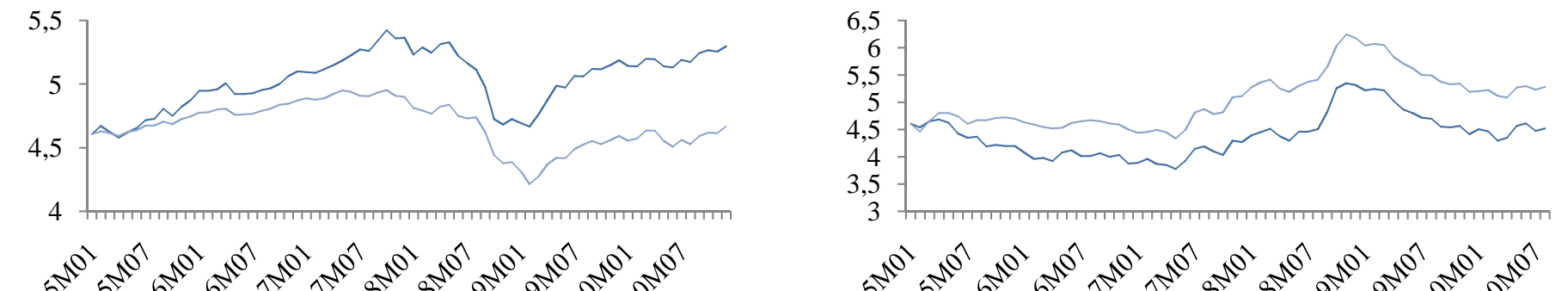

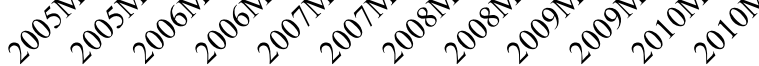

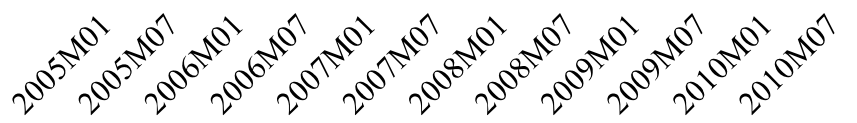

$-\ln (\mathrm{MSCI}$ EM) $\quad-\ln (\mathrm{MSCI}$ World $)$

$-\ln ($ EMBI Global $) \quad-\ln (\mathrm{US} \mathrm{HY})$

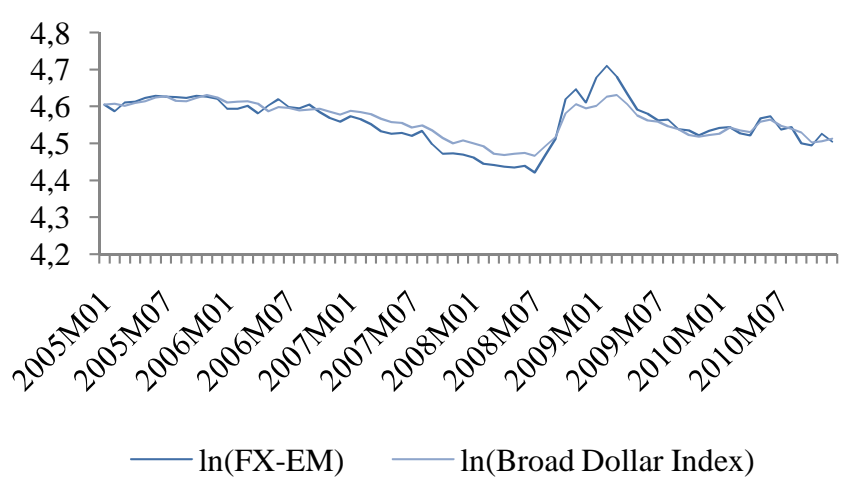




\section{Figure 13}

\section{Crisis equity betas (2008-2009) vs US Holdings}

This figure presents the scatter plot of betas during the crisis (as country-by-country estimations of local returns vs S\&P) against US holdings of foreign equity instruments normalized by equity market capitalization at the end of 2007. ** denotes significance at the $5 \%$ level. Source: Didier et al,. 2010, US Treasury, Bloomberg.

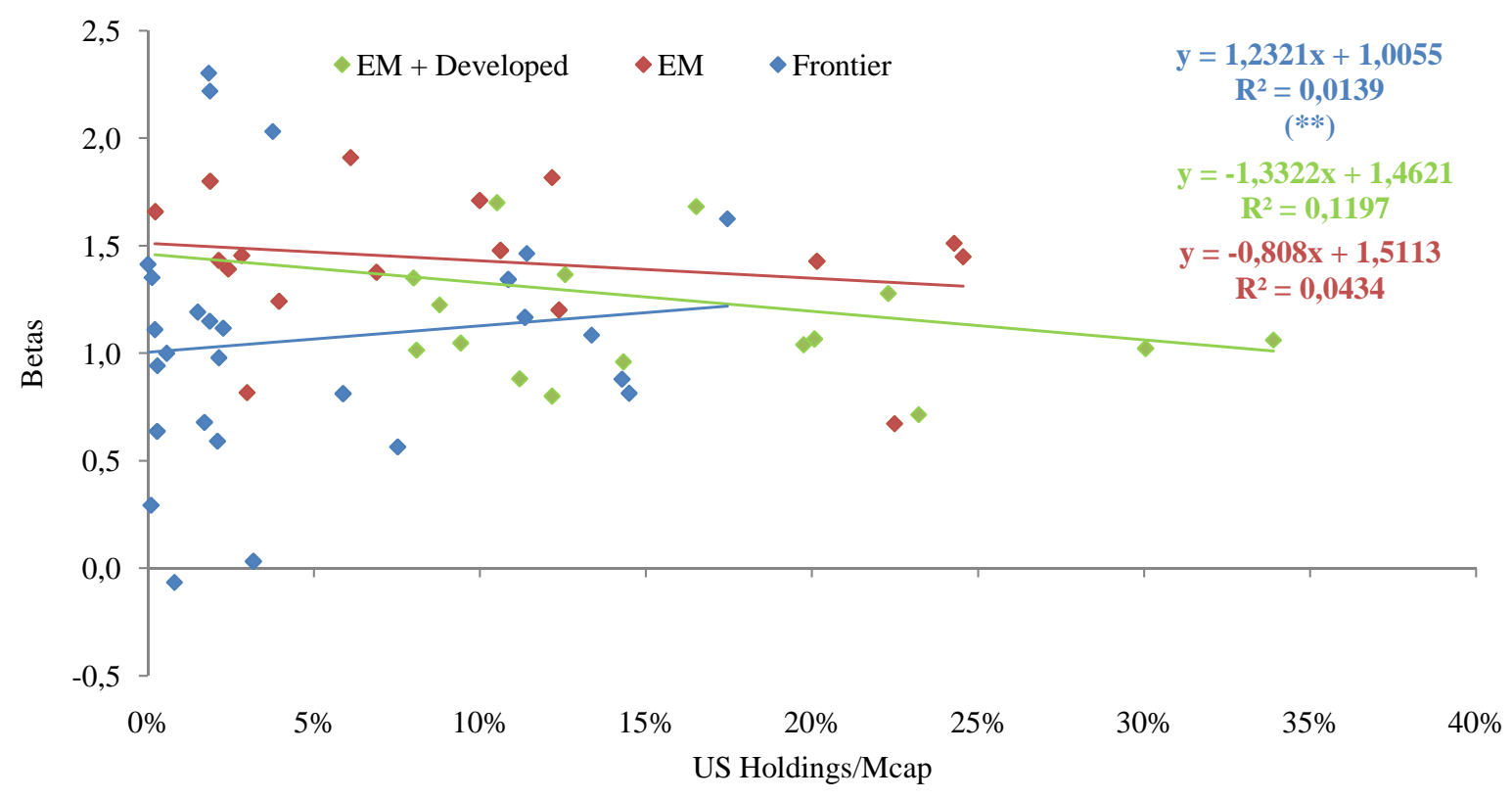

